Prepared for the U.S. Department of Energy

under Contract DE-AC05-76RL01830

\title{
A Survey of Opportunities for Microbial Conversion of Biomass to Hydrocarbon Compatible Fuels
}

I. Jovanovic Tews

S.B. Jones

D.M. Santosa

Z. Dai

K. Ramasamy

Y. Zhu

September 2010

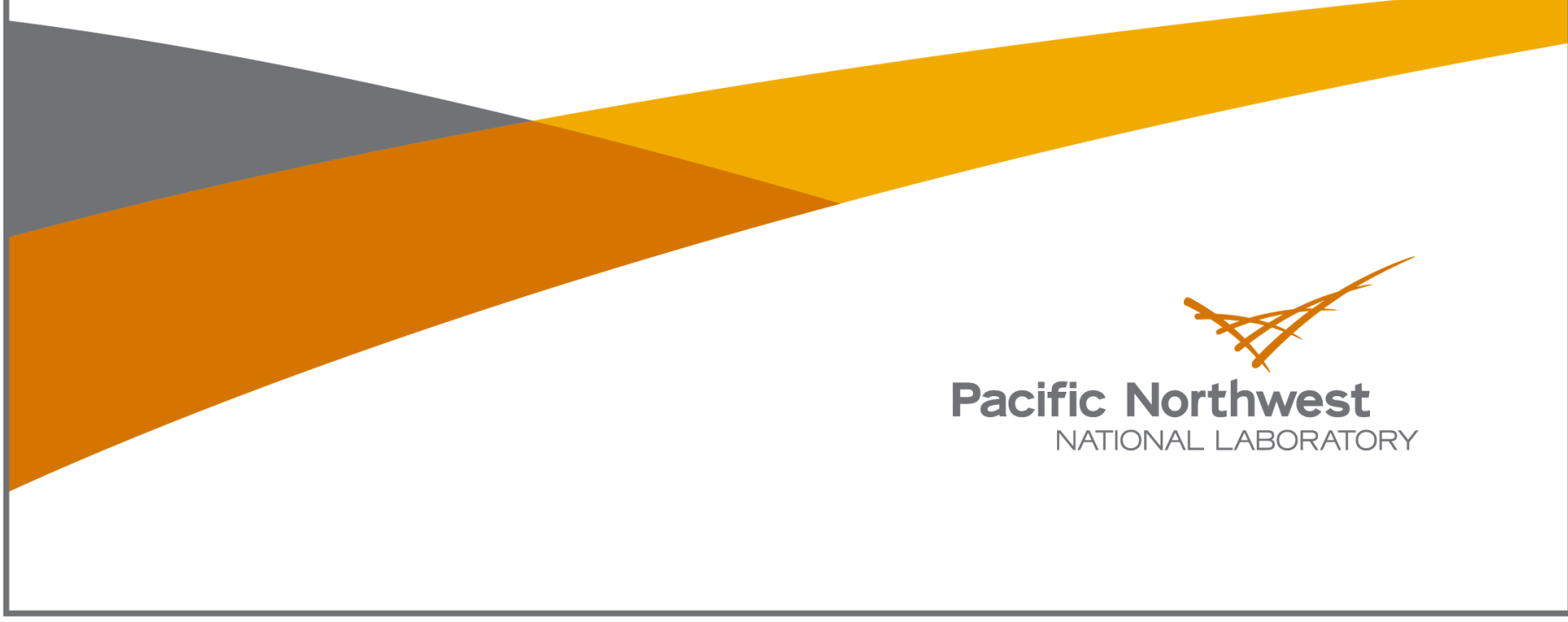





\title{
DISCLAIMER
}

This report was prepared as an account of work sponsored by an agency of the United States Government. Neither the United States Government nor any agency thereof, nor Battelle Memorial Institute, nor any of their employees, makes any warranty, express or implied, or assumes any legal liability or responsibility for the accuracy, completeness, or usefulness of any information, apparatus, product, or process diselosed, or represents that its use would not infringe privately owned rights. Reference herein to any specific commercial product, process, or service by trade name, trademark, manufacturer, or otherwise does not necessarily constitute or imply its endorsement, recommendation, or favoring by the United States Government or any agency thereof, or Battelle Memorial Institute. The views and opinions of authors expressed herein do not necessarily state or reflect those of the United States Government or any agency thereof.

\author{
PACIFIC NORTHWEST NATIONAL LABORATORY \\ operated by \\ BATTELLE \\ for the \\ UNITED STATES DEPARTMENT OF ENERGY \\ under Contract DE-AC05-76RL01830
}

Printed in the United States of America

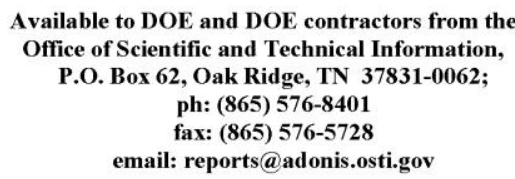

Available to the public from the National Technical Information Service, U.S. Department of Commerce, 5285 Port Royal Rd., Springfield, VA 22161 ph: (800) 553-6847 fax: $(703) 605-6900$

email: orders@ntis.fedworld.gov

online ordering: http://www.ntis.gov/ordering.htm

This document was printed on recycled paper.

$(9 / 2003)$ 


\title{
A Survey of Opportunities for Microbial Conversion of Biomass to Hydrocarbon Compatible Fuels
}

\author{
I. Jovanovic Tews \\ S.B. Jones \\ D.M. Santosa \\ D. Ziyu \\ K. Ramasamy \\ Y. Zhu
}

September 2010

Prepared for

the U.S. Department of Energy

under Contract DE-AC05-76RL01830

Pacific Northwest National Laboratory

Richland, Washington 99352 


\begin{abstract}
Biomass is uniquely able to supply renewable and sustainable liquid transportation fuels. In the near term, the Biomass program has a 2012 goal of cost competitive cellulosic ethanol. However, beyond 2012, there will be an increasing need to provide liquid transportation fuels that are more compatible with the existing infrastructure and can supply fuel into all transportation sectors, including aviation and heavy road transport.

Microbial organisms are capable of producing a wide variety of molecules which can be utilized as potential infrastructure compatible fuels and fuel precursors. These products include higher alcohols, ethers esters fatty acids, alkenes and alkanes. Although some of the biochemical routes are well understood, production of fuels and fuel precursor molecules are in an early stage of research and in most cases not yet ready for commercialization. This is especially true for cases where cellulosic feedstocks are used. Thus, microbial production of hydrocarbon like fuels and precursors is a rich field that has only begun to be exploited. Therefore, the purpose of this report is to present the basic elements of microbial conversion to hydrocarbon fuels and precursors with the intent of providing a basis for future research directions. Specifically, the report covers desired fuel properties, organisms and their synthesis pathways, current research and commercial activities, and economic considerations.
\end{abstract}




\section{Contents}

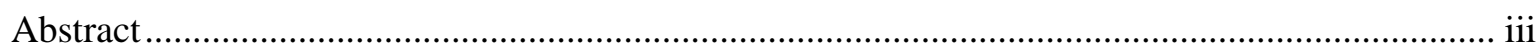

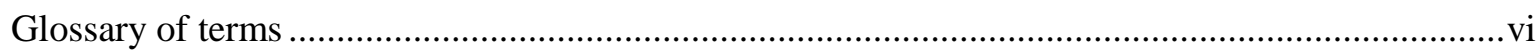

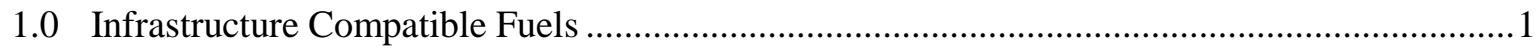

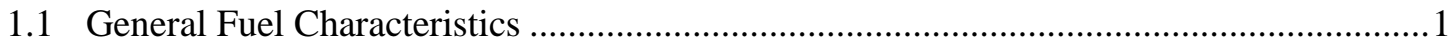

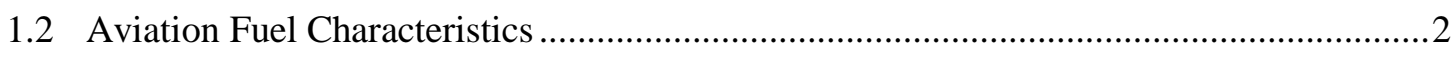

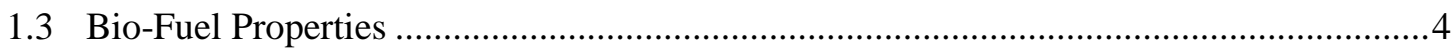

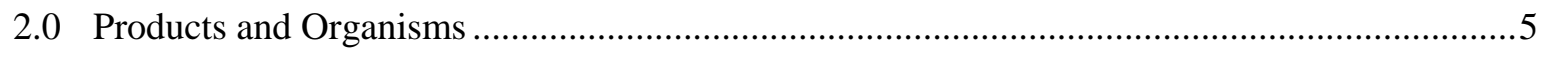

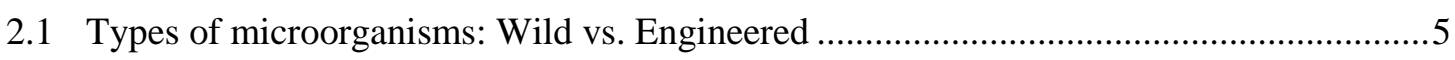

2.2 Biochemical Pathways to Fuels and Fuel Precursors .................................................. 8

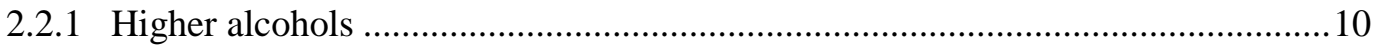

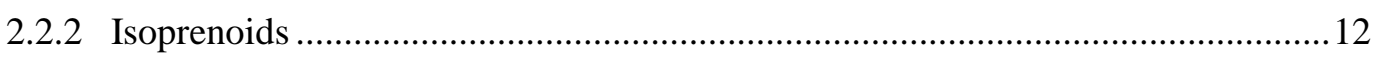

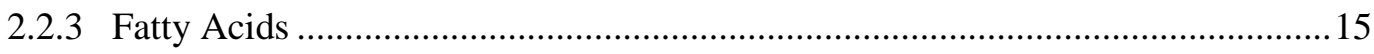

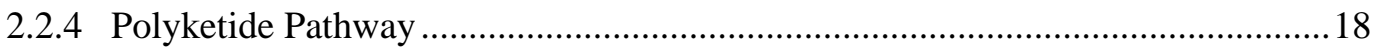

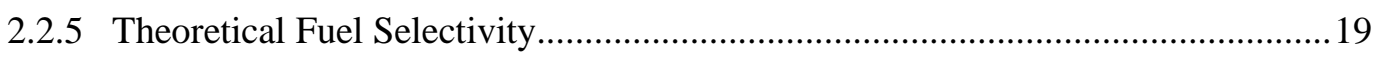

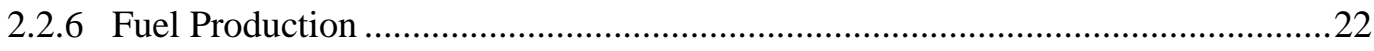

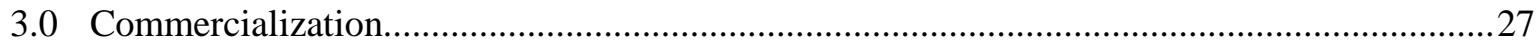

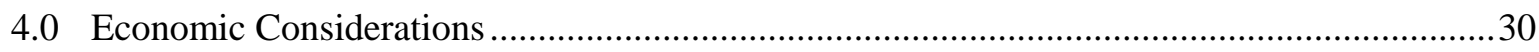

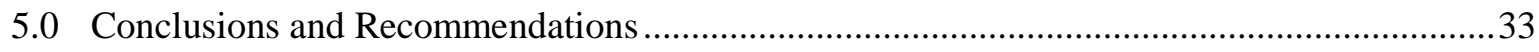

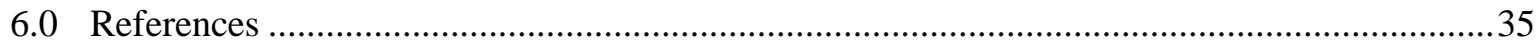

\section{Figures}

Figure 1. Simplified Schema of Fuel Molecules and Precursor Production ................................... 8

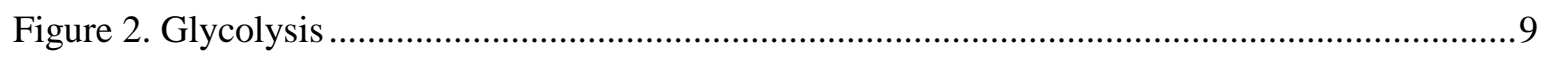

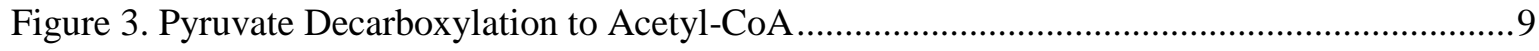

Figure 4. Biosynthesis of n-Butanol, Isopropanol, Acetone and Ethanol ...................................... 11

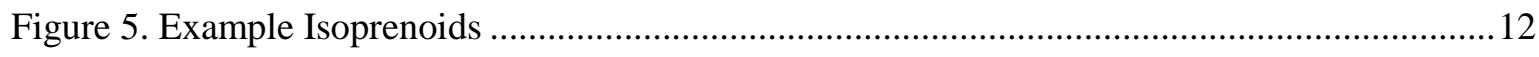

Figure 6. MEV Biosynthetic Pathway .............................................................................. 13

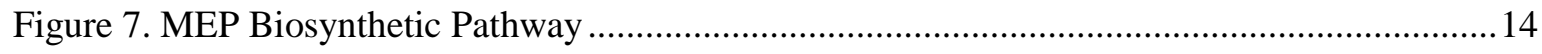

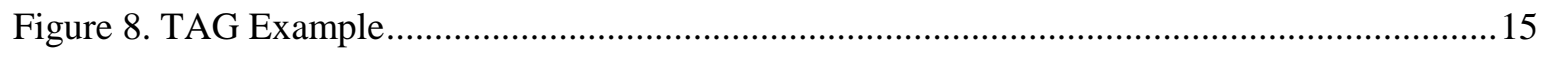

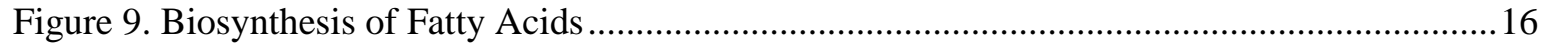

Figure 10. Polyketide Molecule Examples ........................................................................... 19

Figure 11. Conventional and Biofuels Approximate Volatility and Carbon Number ....................22

Figure 12. Biobased and Conventional Fuel Process Pathways to Gasoline Constituents ...............24

Figure 13. Biobased and Conventional Fuel Process Pathways to JP-8 Constituents .....................25 
Figure 14. Biobased and Conventional Fuel Process Pathways to Diesel Constituents .................26

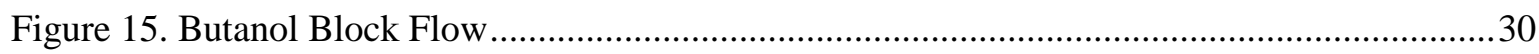

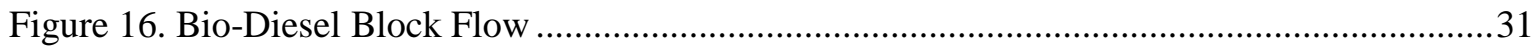

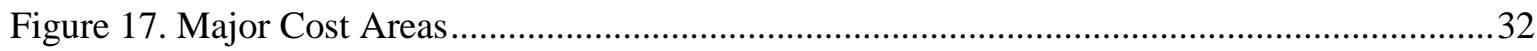

\section{Tables}

Table 1. Properties of Conventional and Current Bio-Base Fuels .................................................2

Table 2. Properties of Conventional Jet Fuels ..............................................................................

Table 3. Extracellular Hydrocarbon and Hydrocarbon Precursors ...................................................6

Table 4. Intracellular Hydrocarbon and Hydrocarbon Precursor Producing Microbes .....................7

Table 5. Classification of Terpenoids Based on Number of Isoprene Units...................................12

Table 6. Polyketide Summary (Hertwick 2009) .......................................................................... 18

Table 7. Stoichiometry, Theoretical Selectivity and Yields .......................................................2

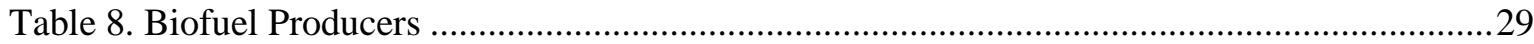




\section{Glossary of terms}

\begin{tabular}{|c|c|}
\hline ACP & Acyl carrier protein \\
\hline$A D P$ & $\begin{array}{l}\text { Adenosine diphosphate, an end-product that results when ATP loses one of its } \\
\text { phosphate groups }\end{array}$ \\
\hline ATP & $\begin{array}{l}\text { Adenosine triphosphate, a coenzyme that transports chemical energy within cells } \\
\text { for metabolism. }\end{array}$ \\
\hline Bio-hydrocarbon & Biologically produced hydrocarbons \\
\hline Co- $A$ & $\begin{array}{l}\text { Coenzyme A, a coenzyme that carries acyl groups (e.g., acetyl, malonyl, etc.) used } \\
\text { in biosynthesis, or the acyl groups may be oxidized for energy production via the } \\
\text { citric acid cycle. }\end{array}$ \\
\hline CTP & Cytidine-monophosphate, \\
\hline CMP & Cytidine-triphosphate, a high energy molecule equal to ATP but more specific \\
\hline DMAPP & Dimethylallyl diphosphate, Isomer of IPP, a precursor to isoprenoids. \\
\hline FAME & Fatty Acid Methyl Esters \\
\hline IPP & Isopentenyl diphosphate; precursor to isoprenoids \\
\hline Isoprenoids & $\begin{array}{l}\text { Also known as terpenes, are formed by the joining of two to eight } \\
\text { five-carbon isoprene units followed by modifications. They represent a family } \\
\text { of thousands of compounds (e.g., rubber, cholesterol, pinene). }\end{array}$ \\
\hline MEP & 2-methylerythritol 4-phosphate, a precursor of terpenes and steroids \\
\hline Mitochondria & $\begin{array}{l}\text { An organelle that supplies most of the ATP for the cell as well other } \\
\text { Important cellular processes such as cell signalling, cell differentiation, and cell } \\
\text { death. }\end{array}$ \\
\hline$M E V, M V A$ & $\begin{array}{l}\text { Mevalonic acid, a precursor to the mevalonate pathway that produces terpenes and } \\
\text { steroids. }\end{array}$ \\
\hline$N A D+$ & $\begin{array}{l}\text { Nicotinamide Adenine Dinucleotide, a coenzyme found in all living cells and } \\
\text { involved in redox reactions, carrying electrons from one reaction to another. }\end{array}$ \\
\hline NADH & Reduced form of NAD ${ }^{+}$ \\
\hline$N A D P+$ & $\begin{array}{l}\text { Nicotinamide Adenine Dinucleotide Phosphate, an important coenzyme in anabolic } \\
\text { reactions such as lipid and nucleic acid synthesis }\end{array}$ \\
\hline NADPH & Reduced form of NADP ${ }^{+}$. \\
\hline Polyketides (PKS) & $\begin{array}{l}\text { A family of molecules formed by the condensation of malonyl-CoA and } \\
\text { acetyl-CoA units followed by various modifications }\end{array}$ \\
\hline$P P P$ & Pentose Phosphate Pathway \\
\hline Pyruvate & $\begin{array}{l}\text { A key intermediate at the intersection of many metabolic pathways. } \\
\text { It is generally produced from sugars via glycolysis. }\end{array}$ \\
\hline$S C O$ & Single Cell Organism \\
\hline
\end{tabular}




\subsection{Infrastructure Compatible Fuels}

The Energy Independence and Security Act of 2007 (EISA) mandates the increased supply of alternative fuels meeting the Renewable Fuel Standard. This requires fuel sold in the U.S. to contain a minimum of 36 billion gallons of fuels, including advanced and cellulosic bio-fuels by 2022. The U.S. Department of Energy (DOE) has set a goal in its Strategic Plan to promote energy diversity and independence. In particular, the DOE Energy Efficiency and Renewable Energy (EERE) Biomass Program supports four key priorities: 1) reduce dependence on foreign oil, 2) promote diverse, sustainable, domestic energy resources, 3) reduce carbon emissions and 4) establish a domestic biomass industry (MYPP 2010).

Biomass is uniquely able to supply renewable and sustainable liquid transportation fuels. In the near term, the Biomass program has a 2012 goal of cost competitive cellulosic ethanol. However, beyond 2012 there will be an increasing need to provide infrastructure compatible liquid transportation fuels which can supply all transportation sectors, including aviation and heavy road transport. Microbial biotechnology has the ability to supply these types of fuels through a wide range of metabolic pathways which produce desirable molecules for fuel production. These molecules include higher alcohols, ethers, esters, fatty acids, alkenes and alkanes, and can serve as fuel precursors or end infrastructure compatible fuels. This report surveys several types of molecules derived from microbial metabolic pathways, and is meant to be used as fundamental information for further research and process development in this area. It is important to note that microbial processes reviewed here would utilize cellulosic feedstocks as the primary carbon source and that currently these pathways are not commercialization ready. As such, ethanol, biodiesel from plant oils, algal oils, hydrogen and methane are not addressed in this report.

\subsection{General Fuel Characteristics}

In order to achieve liquid hydrocarbon compatible fuels several key bulk properties and molecular characteristics need to be met. Such bulk properties include:

- miscible with existing hydrocarbon fuels,

- meets fuel performance characteristics,

- good storability,

- transportable in existing infrastructure, and

- requires no change to end uses (equipment or vehicles).

By implication, infrastructure compatible bio-based fuel molecules should also have the following desirable characteristics:

- low oxygen content,

- low water solubility, and

- a high degree of saturation.

In short, infrastructure compatible fuels should look and act just like existing liquid fuels, and users should not be able to distinguish between petroleum based and bio-based fuel. Table 1 shows representative properties of conventional fuels and existing bio-fuels. Existing bio-fuels meet some of the requirements, but not all. For example, ethanol has a boiling point within the gasoline range, but a low 
heating value. Bio-diesel as a diesel blend component has acceptable cetane, but the viscosity and freeze points may be too high in cold weather; it is also unacceptable as a jet fuel.

Table 1. Properties of Conventional and Current Bio-Base Fuels

\begin{tabular}{|c|c|c|c|c|c|c|}
\hline & $\begin{array}{c}\text { Representative } \\
\text { molecule(s) }\end{array}$ & $\begin{array}{c}\text { Carbon \# } \\
\text { range }\end{array}$ & $\begin{array}{c}\text { Net heating } \\
\text { value } \mathbf{k J} / \mathbf{k g} \\
\text { (Btu/gal) }\end{array}$ & $\begin{array}{l}\text { Boiling Point } \\
\text { or Approx. } \\
\text { Distillation } \\
\text { Range, }{ }^{\circ} \mathbf{C}\end{array}$ & $\begin{array}{c}\text { Density } \\
\text { at } 15^{\circ} \mathrm{C} \\
\mathrm{g} / \mathrm{ml}\end{array}$ & $\begin{array}{l}\text { Other Important } \\
\text { Properties }\end{array}$ \\
\hline Ethanol & $\mathrm{CH}_{3} \mathrm{CH}_{2} \mathrm{OH}$ & $\mathrm{C} 2$ & $\begin{array}{c}26,790 \\
(76,550)\end{array}$ & 65 & 0.794 & \\
\hline $\begin{array}{l}\text { Regular } \\
\text { Gasoline }\end{array}$ & $\begin{array}{c}2,2,4- \\
\text { trimethylpentan } \\
\text { e (isooctane) }\end{array}$ & $\mathrm{C} 4-\mathrm{C} 12$ & $\begin{array}{c}43,330 \\
(114,200)\end{array}$ & $\begin{array}{c}40-200 \\
\text { (summer } \\
\text { conventional) }\end{array}$ & 0.735 & Octane $>87$ \\
\hline Jet A & Kerosene type & $\mathrm{C} 8-\mathrm{C} 16$ & $\begin{array}{c}42,850 \\
(122,200)\end{array}$ & $\begin{array}{l}205 \text { (at } 10 \% \\
\text { recovery) - } 300\end{array}$ & 0.80 & $\begin{array}{l}\text { Freeze pt }<-47^{\circ} \mathrm{C} \\
\text { Viscosity, }-20^{\circ} \mathrm{C} 8 \\
\mathrm{~mm}^{2} / \mathrm{sec} \max (\sim 1.2 \\
\left.\text { at } 40^{\circ} \mathrm{C}\right)\end{array}$ \\
\hline $\begin{array}{l}\text { No.2-D } \\
\text { Diesel }\end{array}$ & $\mathrm{n}-\mathrm{C}_{16}$ (cetane) & $\mathrm{C} 10-\mathrm{C} 22$ & $\begin{array}{c}42,640 \\
(130,000)\end{array}$ & $130-390$ & 0.850 & $\begin{array}{l}\text { Viscosity, } 40^{\circ} \mathrm{C} \\
1.9-4.1 \mathrm{~mm}^{2} / \mathrm{sec} \\
\text { Flash }>52^{\circ} \mathrm{C} \\
\text { Cetane }>40\end{array}$ \\
\hline $\begin{array}{l}\text { Bio-diesel } \\
\text { (as a blend } \\
\text { stock) }\end{array}$ & $\begin{array}{c}\mathrm{n}-\mathrm{C}_{17} \mathrm{H}_{35^{-}} \\
\mathrm{COOCH}_{3} \text { (fatty } \\
\text { acid methyl } \\
\text { ester) }\end{array}$ & $\mathrm{C} 12-\mathrm{C} 22$ & $\begin{array}{c}40,600 \\
(128,000)\end{array}$ & $\begin{array}{c}330-360 \text { (at } \\
90 \% \text { recovery) }\end{array}$ & 0.880 & $\begin{array}{l}\text { Freeze pt } \sim 0^{\circ} \mathrm{C} \\
\text { Viscosity, } 40^{\circ} 1.9-6.0 \\
\mathrm{~mm}^{2} / \mathrm{sec} \\
\text { Cetane }>44\end{array}$ \\
\hline
\end{tabular}

\subsection{Aviation Fuel Characteristics}

Aviation fuel specifications are more stringent than motor fuels. A 2009 study from the Rand Corporation (Hileman 2009) identified the following characteristics as being necessary for acceptable aviation fuel:

- high energy density for efficient long range flights,

- high flash point for safety,

- low freeze point for high altitude flights, and

- thermal stability, which allows use for engine cooling. 
Table 2 summarizes the properties for Jet A and JP-8 (extracted from Table 2.3 Kinder 2009) and their associated tests.

Table 2. Properties of Conventional Jet Fuels

\begin{tabular}{|c|c|c|c|}
\hline & Jet A/Jet A-1 & JP-8 & ASTM Test Method \\
\hline \multicolumn{4}{|l|}{ COMPOSITION } \\
\hline Acidity, total mg KOH/g (max) & 0.10 & 0.015 & D3242 \\
\hline Aromatics volume \% (max) & 25 & 25 & D1319 \\
\hline Aromatics volume \% (max) & 26.5 & & D6379 \\
\hline Sulfur, mercaptan, mass $\%$ (max) & 0.003 & 0.002 & D3227 \\
\hline Sulfur, total mass \% (max) & 0.3 & 0.30 & D1266,D2622, D4294 or D5453 \\
\hline \multicolumn{4}{|l|}{ VOLATILITY } \\
\hline Distillation & & & D2887 or D86 \\
\hline $10 \%$ recovered, ${ }^{\circ} \mathrm{C}(\max )$ & 205 & $157-205$ & \\
\hline $50 \%$ recovered, ${ }^{\circ} \mathrm{C}(\max )$ & Report & $168-229$ & \\
\hline $90 \%$ recovered, ${ }^{\circ} \mathrm{C}(\max )$ & Report & $183-262$ & \\
\hline Final Boiling Pt., ${ }^{\circ} \mathrm{C}(\max )$ & 300 & 300 & \\
\hline Distillation residue, \% (max) & 1.5 & 1.5 & \\
\hline Distillation loss, \% (max) & 1.5 & 1.5 & \\
\hline Flash Point, ${ }^{\circ} \mathrm{C}(\min )$ & 38 & $38-68$ & D56 or D3828 \\
\hline Density at $15^{\circ} \mathrm{C}, \mathrm{kg} / \mathrm{l}$ & $0.775-0.840$ & $0.775-0.840$ & D1298 or D4052 \\
\hline \multicolumn{4}{|l|}{ FLUIDITY } \\
\hline Freezing point, ${ }^{\circ} \mathrm{C}(\max )$ & $\begin{array}{l}-40 \text { Jet } A \\
-47 \text { Jet } A-1\end{array}$ & -47 & D5972, D7153, D7154 or D2386 \\
\hline Viscosity $-20^{\circ} \mathrm{C}, \mathrm{mm}^{2} / \mathrm{s}(\max )$ & 8.0 & 8.0 & D445 \\
\hline \multicolumn{4}{|l|}{ COMBUSTION } \\
\hline Net heat of combustion, $\mathrm{MJ} / \mathrm{kg}$ (min) & 42.8 & 42.8 & D4529, D3338, D7154 or D2386 \\
\hline Hydrogen content, mass \% (min) & & 13.4 & \\
\hline $\begin{array}{l}\text { Smoke point, mm (min) } \\
\text { OR }\end{array}$ & 25 & 25 & D1322 \\
\hline Smoke point, $\mathrm{mm}(\mathrm{min})$ and & 18 & 19 & D1322 \\
\hline Naphthalenes, vol ume \% (max) & 3.0 & 3.0 & D1840 \\
\hline \multicolumn{4}{|l|}{ CORROSION } \\
\hline Copper strip, $2 \mathrm{~h}$ at $100^{\circ} \mathrm{C}(\max )$ & No. 1 & No. 1 & D130 \\
\hline \multicolumn{4}{|l|}{ THERMAL STABILITY } \\
\hline JFTOT (2.5 h at control temp) & 260 & & D3241 \\
\hline Temperature, ${ }^{\circ} \mathrm{C}(\mathrm{min})$ & 25 & 25 & \\
\hline Filter pressure drop, $\mathrm{mmHg}(\max )$ & 3 & 3 & \\
\hline \multicolumn{4}{|l|}{ CONTAMINANTS } \\
\hline Existent gum, mg/100 ml (max) & 7 & 7 & D381, IP 540 \\
\hline
\end{tabular}

It is unlikely that a single compound biofuel will be able to meet all of these requirements. Hence, infrastructure compatible fuels will likely be a mix of hydrocarbons spanning the given boiling point range and comprised of a variety of compound types (aromatic, naphthene and paraffin). 


\subsection{Bio-Fuel Properties}

It is likely that new fuels will have properties that are not accounted for by existing tests, such as trace contaminants, materials compatibility (such as seal swell) and boiling point distributions that differ from standard specifications. For example, single compound bio-fuels will likely be blendable with conventional fuels only in small quantities before the boiling point distribution is significantly altered. Just as important, commodity liquid fuels must have low production costs to be economic. Ultimately the key goal is to identify economic production pathways to alternative infrastructure compatible renewable fuels and chemicals.

Cellulosic derived bio-based infrastructure compatible fuels are still in the early stages of development. Several organisms have already been identified for their natural hydrocarbon or hydrocarbon precursor production. Among these are strains in both the fungal (including yeast) and bacterial kingdoms. Biohydrocarbon commercialization based on non-cellulosic feedstocks has already begun in industry and several companies that rely on novel biotechnology as their core capability have been identified. This report is an overview of where this industry stands and is divided into three parts: 1) organisms and products, 2) commercialization and 3) economics. The purpose here is to provide a preliminary survey of several exemplary bio-hydrocarbon strains and their biochemical pathways. Secondly, to review the current commercial companies using the wild type strain of these organisms as well as developing genetic modifications in pursuit of higher product titer. Lastly techno-economic analyses are presented for the production of bio-butanol and for lipids as these two classes bracket the range from small molecules to large ones. 


\subsection{Products and Organisms}

Currently many of the wild type and genetically engineered organisms considered for hydrocarbon production are used in industry for the production of food products, pharmaceuticals, ethanol fuel and other commodities. However research has indicated that some of these organisms are capable of producing compounds such as higher alcohols, converting acetate to methane, and producing long-chain alkenes and $n$-alkanes. These products are not only useful fuels but are important precursors in the petroleum industry for other fuel and chemical development. Several recent useful reviews summarize the organisms and pathways to fuels (Wackett 2008, Keasling 2008, Antizar-Ladislao 2008, Rude 2009, Yan 2009, Rottig 2010, Li 2010).

In the process of investigating the aforementioned bio-hydrocarbon production pathways, several key issues were identified. First, the organisms need to possess the specific biochemical pathways containing enzymes that act as bio-catalysts in the production of the fuel molecules. Pathways containing these enzymes and desired products are either native or can be genetically engineered in order to achieve higher titers of product. Second, the organism's thermodynamic requirements must be satisfied to drive the biochemical reactions to products. In short the availability of chemical energy from Adenosine Triphosphate (ATP) and reducing equivalents from Nicotinamide Adenine Dinucleotide (NAD+) or Nicotinamide Adenine Dinucleotide Phosphate (NADP+) must be met. And lastly, the need for higher production rates drives the investigation of possible growth condition optimizations through changes in media, temperature, and pressure.

To address these issues it is important to understand not only the type of hydrocarbon products and their synthesis pathways, but also the metabolic complexities of the native organism. Currently companies with major investments in the alcohol or bio-hydrocarbon production industry have already begun establishing research and development protocols for these alternative fuels options. However development of infrastructure compatible bio-hydrocarbon and alcohols will demand an economically viable production process with high product yields and low process and capital costs. Simultaneously, organisms have to equally satisfy their own demands for growth and development as well as overcome natural genetic regulatory mechanisms preventing high product yields.

\subsection{Types of microorganisms: Wild vs. Engineered}

Microbes can be broadly classified as either wild type or genetically engineered organisms. Wild type microorganisms are those that possess the relevant biochemical pathways in their native state. Many companies and research institutions are still in the process of screening different organisms for production of particular fuel molecules. Wild type microbes generally have low selectivity and yield with respect to the products of interest. In order to achieve maximum yields and selectivity, growth parameter and culture media optimizations become the priority research and process development focus.

Through genetic engineering practices, wild type organisms can be equipped with non-native biochemical pathways which improve overall organism function and desired production of specific products. With appropriate manipulation of the biosynthetic pathway genes and/or other regulatory genes and pathways organisms may be designed to have higher yield and selectivity for specific products. 
With additional modifications, these microorganisms can also be engineered to be more resistant towards adverse growth conditions, such as hydrolysate inhibitor resistance, which in turn can result in increased yields or rates of production.

Both wild type and engineered strains are being studied extensively for their fuel production characteristics (Ladygina 2006, Fortman 2008, Lee 2008). Table 1 in the previous section lists some of the characteristics that these products need to meet. Many of these microorganisms employ specific biochemical pathways in producing what is known as fuel-type molecules. These molecules may include:

- higher alcohols

- isoprenoids

- fatty acids and triglycerides

- polyketides

Product recovery is simplified if the microorganisms produces it outside the cell. Table 3 lists some extracellular organisms and their concentrations.

Table 3. Extracellular Hydrocarbon and Hydrocarbon Precursors

\begin{tabular}{|c|c|c|c|c|}
\hline Microorganisms & $\begin{array}{l}\text { Product } \\
\text { Class }\end{array}$ & Product Range & $\begin{array}{l}\text { \% of Biomass or } \\
\text { concentration }\end{array}$ & Reference \\
\hline \multicolumn{5}{|l|}{$\begin{array}{l}\text { Gram-negative } \\
\text { facultatively anaerobic } \\
\text { bacteria }\end{array}$} \\
\hline E.Coli (modified) & alcohols & isopentanol & $1.2 \mathrm{~g} / \mathrm{L}$ & Atsumi 2008 \\
\hline E.Coli (modified) & alcohols & n-butanol & $0.5 \mathrm{~g} / \mathrm{L}$ & Atsumi 2008 \\
\hline E.Coli (modified) & alcohols & isobutanol & $20 \mathrm{~g} / \mathrm{L}$ & Atsumi 2008 \\
\hline \multicolumn{5}{|l|}{$\begin{array}{l}\text { Gram-positive aerobic } \\
\text { bacteria (eubacteria) }\end{array}$} \\
\hline $\begin{array}{l}\text { Clostridium acetobutylicum } \\
\text { PJC4BK (GMM)* }\end{array}$ & $\begin{array}{l}\text { mixed } \\
\text { oxygenates }\end{array}$ & acetone-butanol-ethanol & $25-33 \mathrm{~g} / \mathrm{L}$ & Ezeji 2007 \\
\hline $\begin{array}{l}\text { C.acetobutylicum P260 } \\
(\mathrm{GMM})^{*}\end{array}$ & $\begin{array}{l}\text { mixed } \\
\text { oxygenates }\end{array}$ & acetone-butanol-ethanol & $25-34 \mathrm{~g} / \mathrm{L}$ & Ezeji 2007 \\
\hline $\begin{array}{l}\text { C.beijerinckii BA101 } \\
\text { (GMM)* }\end{array}$ & $\begin{array}{l}\text { mixed } \\
\text { oxygenates }\end{array}$ & acetone-butanol-ethanol & $25-35 \mathrm{~g} / \mathrm{L}$ & Ezeji 2007 \\
\hline $\begin{array}{l}\text { C.beijerinckii BA101 } \\
\text { (GMM)* } \\
\text { Fungi (endophytic) }\end{array}$ & alcohol & butanol & $11.9-14.3 \mathrm{~g} / \mathrm{L}$ & Ezeji 2005 \\
\hline $\begin{array}{l}\text { Gliocladium roseum (NRRL } \\
\text { 50072) }\end{array}$ & $\begin{array}{l}\text { Volatile } \mathrm{HCs} \\
\text { and } \mathrm{HC} \\
\text { derivatives }\end{array}$ & C5-C11vapor phase & 4 ppmv & Stobel 2008 \\
\hline
\end{tabular}

Table 4 lists organisms that produce hydrocarbons and hydrocarbon precursors and their production rates. Most of the data compiled in Table 4 are from a review by Ladygina (2006) that summarizes microorganisms that produce true hydrocarbons. Many of the organisms produce very low amounts of fuel, typically less than $1 \%$ of their dry weight. A few specific oleaogenous organisms accumulate significant amounts of oxygenated oil. 
Table 4. Intracellular Hydrocarbon and Hydrocarbon Precursor Producing Microbes

\begin{tabular}{|c|c|c|c|c|}
\hline Microorganisms & $\begin{array}{l}\text { Product } \\
\text { Class }\end{array}$ & Product Range & $\begin{array}{l}\text { \% of Biomass or } \\
\text { concentration }\end{array}$ & Reference \\
\hline \multicolumn{5}{|l|}{ Cyanobacteria } \\
\hline N. muscorum & alkanes & $\begin{array}{l}\text { n-C15-C18;7 \& 8- } \\
\text { methylheptadecanes }\end{array}$ & $0.025-0.12$ & Ladygina 2006 \\
\hline Trichodesmium erythaeum & alkanes & $\mathrm{n}-\mathrm{C} 15-\mathrm{C} 18$ & $0.05-0.12$ & Ladygina 2006 \\
\hline Coccochloris elabens & alkanes & n-C18;C17:1;C19:1;C19:2 & $0.05-0.12$ & Ladygina 2006 \\
\hline Plectonema terebrans & alkanes & $\mathrm{n}-\mathrm{C} 15-\mathrm{C} 18 ; \mathrm{C} 17: 1$ & $0.05-0.12$ & Ladygina 2006 \\
\hline \multicolumn{5}{|l|}{$\begin{array}{l}\text { Anaerobic phototrophic } \\
\text { bacteria }\end{array}$} \\
\hline Rhodopseudomonas & isoprenoids & $\mathrm{n}-\mathrm{C} 15-\mathrm{C} 20$ & 0.006 & Ladygina 2006 \\
\hline Rhodospirillum rubrum & isoprenoids & $\mathrm{n}-\mathrm{C} 15-\mathrm{C} 21$ & 0.005 & Ladygina 2006 \\
\hline \multicolumn{5}{|l|}{$\begin{array}{l}\text { Gram-negative anaerobic } \\
\text { sulfate-reducing bacteria }\end{array}$} \\
\hline D.desulfuricans & alkanes & $\mathrm{n}-\mathrm{C} 11-\mathrm{C} 35$ & $0.8-2.25$ & Ladygina 2006 \\
\hline \multicolumn{5}{|l|}{$\begin{array}{l}\text { Gram-negative } \\
\text { facultatively anaerobic } \\
\text { bacteria }\end{array}$} \\
\hline V.Ponticus, V. Marinus & alkanes & $\mathrm{n}-\mathrm{C} 15-\mathrm{C} 18$ & 0.03 & Ladygina 2006 \\
\hline E.Coli (modified) & isoprenoids & $\begin{array}{l}\text { Mono-, di-, sesqui- } \\
\text { terpenoids,carotenoids }\end{array}$ & $<0.045$ & Maury 2005 \\
\hline E.Coli & mixed $\mathrm{HC}$ & $\mathrm{C} 13-\mathrm{C} 23$ & 0.0035 & Ladygina 2006 \\
\hline \multicolumn{5}{|l|}{$\begin{array}{l}\text { Gram-positive aerobic } \\
\text { bacteria (eubacteria) }\end{array}$} \\
\hline Bacillus sp. & mixed $\mathrm{HC}$ & C14-C34 & 0.33 & Ladygina 2006 \\
\hline S.Lutea & mixed $\mathrm{HC}$ & C23:1-C30:1 & 0.4 & Ladygina 2006 \\
\hline Arthrobacter sp. & mixed $\mathrm{HC}$ & $\mathrm{C} 15-\mathrm{C} 34$ & 0.93 & Ladygina 2006 \\
\hline Micrococcus sp. & mixed $\mathrm{HC}$ & $\mathrm{C} 17-\mathrm{C} 30$ & 0.68 & Ladygina 2006 \\
\hline Corynebacterium sp. & mixed $\mathrm{HC}$ & $\mathrm{C} 15-\mathrm{C} 33$ & 0.17 & Ladygina 2006 \\
\hline Mycobacterium sp. & mixed $\mathrm{HC}$ & C17-C31 & 2.69 & Ladygina 2006 \\
\hline \multicolumn{5}{|l|}{ Yeasts } \\
\hline Saccharomyces sp. & mixed $\mathrm{HC}$ & C17-C34 & 0.04 & Ladygina 2006 \\
\hline Saccharomyces cerevisiae & isoprenoids & $\begin{array}{l}\text { sesquiterpenoids, } \\
\text { carotenoids }\end{array}$ & $\begin{array}{l}370 \mu \mathrm{g} / \mathrm{L} \& \\
0.001 \%\end{array}$ & Maury 2005 \\
\hline S. oviformis & mixed $\mathrm{HC}$ & C10-C31 & 1.6 & Ladygina 2006 \\
\hline $\begin{array}{l}\text { S. oviformis, } S \text {. ludwigii } \\
\text { (anaerobically grown) }\end{array}$ & isoprenoids & C10-C31 & $3.6-10.2$ & Ladygina 2006 \\
\hline Cryptococcus curvatus & lipids & C16-C18 & $58-60 \%$ & Ratledge 2008 \\
\hline Lipomyces starkeyi & lipids & C16-C18 & $63-65 \%$ & Ratledge 2008 \\
\hline Rhodosporidium toruloides & lipids & C16-C18 & $66 \%$ & Ratledge 2008 \\
\hline Rhodotorula glutinis & lipids & $\mathrm{C} 16-\mathrm{C} 18$ & $72 \%$ & Ratledge 2008 \\
\hline Waltomyces lipofer & lipids & $\mathrm{C} 16-\mathrm{C} 18$ & $64 \%$ & Ratledge 2008 \\
\hline \multicolumn{5}{|l|}{ Fungi (mycelium) } \\
\hline $\begin{array}{l}\text { Penicillium sp, Aspergillus } \\
\text { sp, Tricoderma virida }\end{array}$ & mixed $\mathrm{HC}$ & C15-C36 & $0.06-0.7$ & Ladygina 2006 \\
\hline C.Resinae (glucose-grown) & isoprenoids & $\mathrm{C} 7-\mathrm{C} 36$ & 0.1 & Ladygina 2006 \\
\hline \multicolumn{5}{|l|}{ Fungi (spores) } \\
\hline Ustilago maydis & mixed $\mathrm{HC}$ & $\mathrm{C} 19-\mathrm{C} 23$ & 0.004 & Ladygina 2006 \\
\hline Sphacelotheca reiliana & mixed $\mathrm{HC}$ & C23-C33 & 0.015 & Ladygina 2006 \\
\hline
\end{tabular}




\subsection{Biochemical Pathways to Fuels and Fuel Precursors}

Many of the molecules discussed in this paper are naturally produced within microorganisms through a combination of general and unique biochemical pathways. Very commonly bio-hydrocarbon synthesis pathways begin with catabolism (break-down) of glucose as shown in Figure 1 (adapted from Metzler 2001, Keasling 2008, Rude 2009). From there specific pathways are used by the microorganisms to convert intermediates derived from glucose catabolism to different molecules. Using glucose as the main carbon and energy source, a microorganism can proceed to make many different by-products.

\section{Glucose}

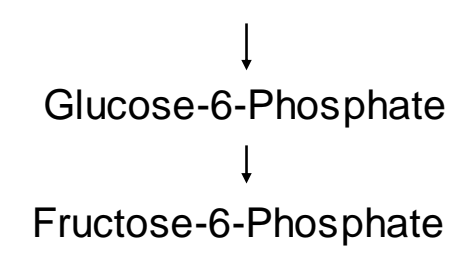

Fructose 1,6-Diphosphate

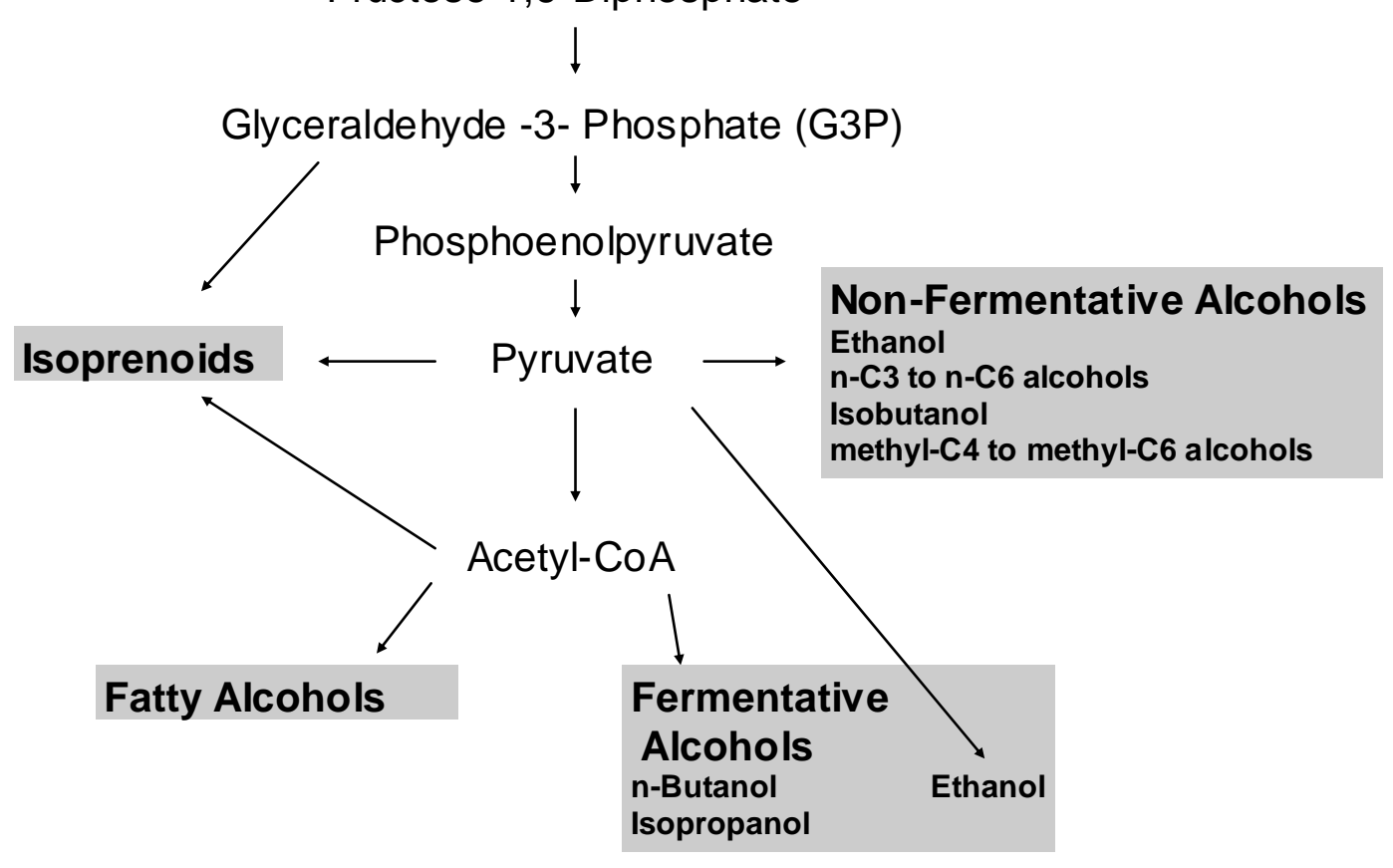

Figure 1. Simplified Schema of Fuel Molecules and Precursor Production

In order to gain better understanding of bio-hydrocarbon production, biochemistry fundamentals are applied to predict possible outcomes for specific fuel precursor molecules. Understanding the choice organism's central metabolic pathways in generating key intermediates is the initial step in determining what the complete pathway to the final fuel product may be. Figure 2 shows the biochemical pathway common to most organisms for conversion of glucose to important intermediates, such as pyruvate. This pathway is called the Embden-Meyerhof-Parnas (EMP) pathway, or simply glycolysis (Metzler 2001). The glycolytic pathway serves dual roles: first it catabolizes glucose to generate chemical energy (ATP) 
and reducing power (NADH) both vital in reaction energy balances. Second, the pathway provides intermediates for building of cellular components (Metzler 2001).<smiles>OCC1OC(O)C(O)C(O)C1O</smiles>

Glucose
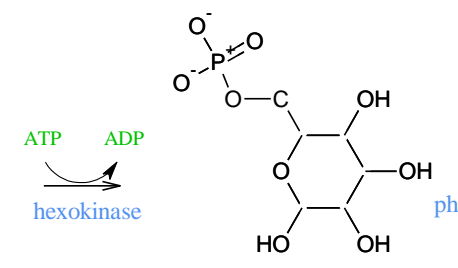

Glucose-6-Phosphate

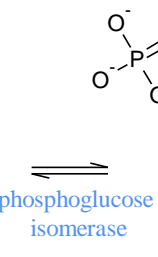

$0, \frac{0}{0}=0$

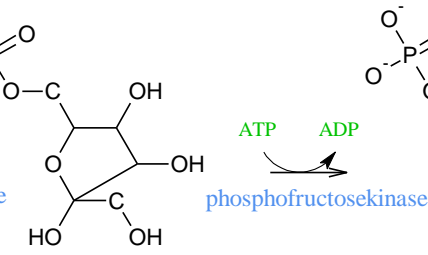

Fructose-6-Phosphate
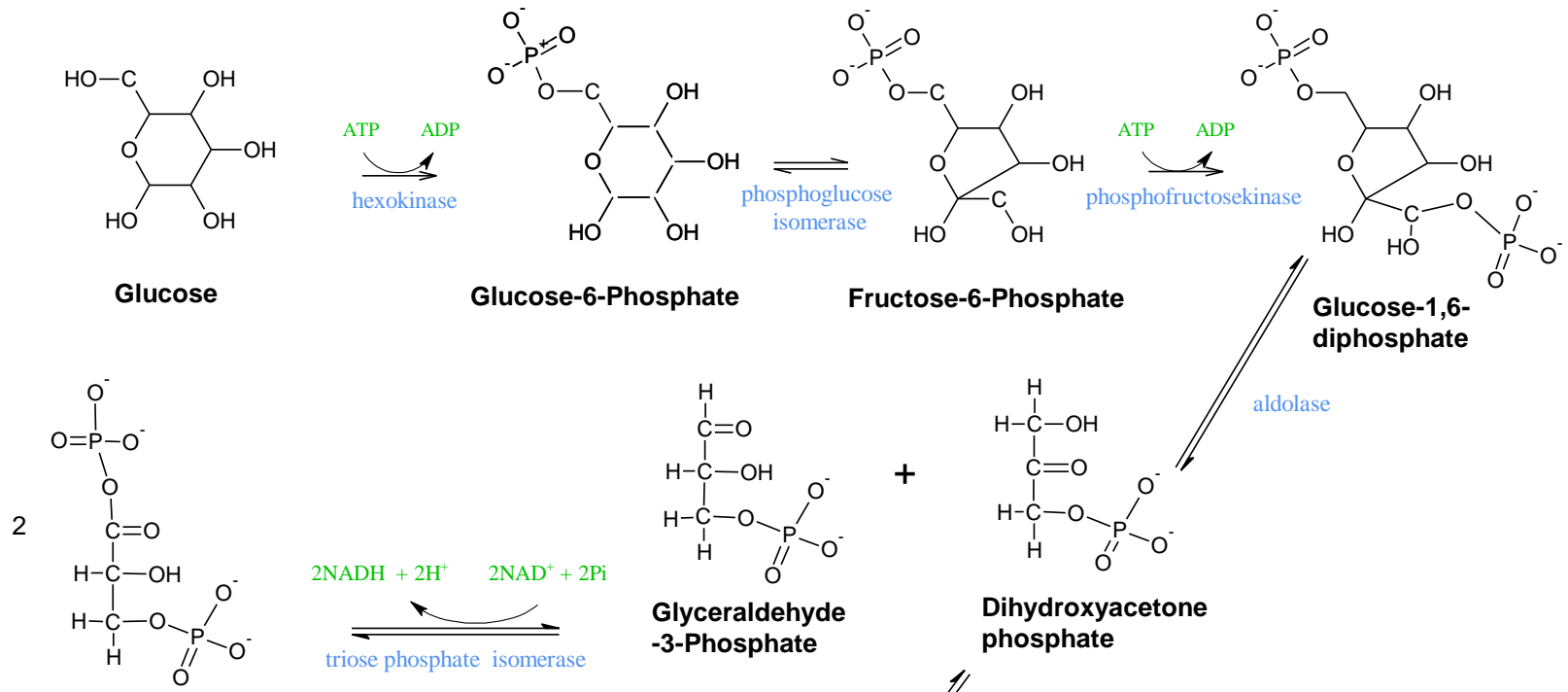

$2 \mathrm{NADH}+2 \mathrm{H}^{+} \quad 2 \mathrm{NAD}^{+}+2 \mathrm{Pi}$
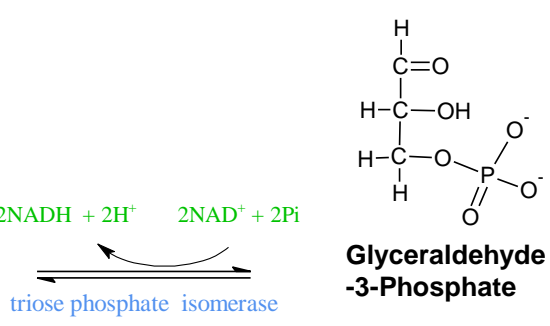

\section{Glyceraldehyde}

-3-Phosphate

1,3-Diphosphoglycerate
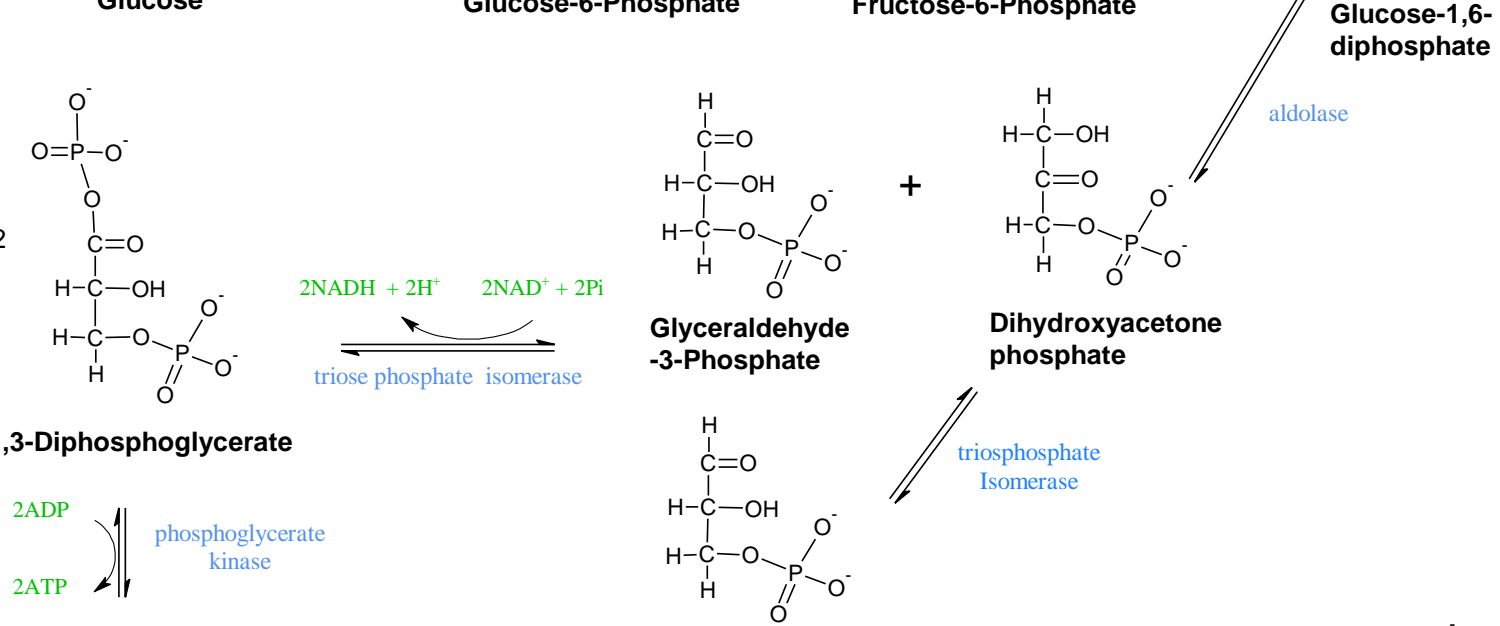

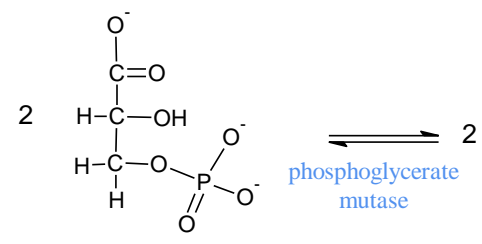

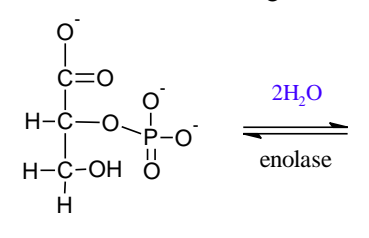

2-Phosphoglycerate

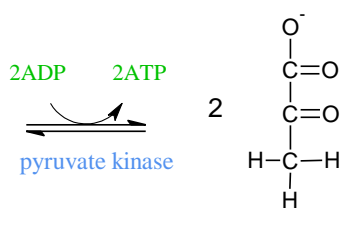

Pyruvate
Phosphoenolpyruvate

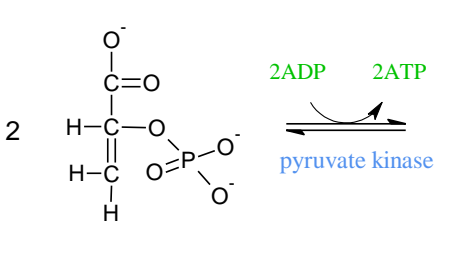

Figure 2. Glycolysis

One of these key intermediates, pyruvate, is decarboxylated under aerobic conditions to acetyl-CoA (Figure 3) which is a precursor to most of the products discussed here. In contrast, under anaerobic conditions pyruvate can be reduced to lactic acid or decarboxylated and reduced to ethanol (Metzler 2001).<smiles>CC(=O)[O-]</smiles>

Pyruvate

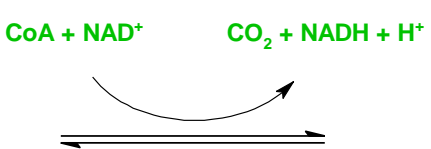

Acetyl-CoA

Figure 3. Pyruvate Decarboxylation to Acetyl-CoA

Under aerobic conditions acetyl-CoA can be used in biosynthesis of cellular constituents such as amino acids through the well understood pathways such as the citric acid cycle. Alternatively acetyl-CoA can be 
consumed (released as $\mathrm{CO}_{2}$ ) in the citric acid cycle, generating reduced cofactors (NADH and $\mathrm{FADH}_{2}$ ) in the process. These reduced cofactors can be respired to generate ATP (e.g., up to 3 ATP per NADH) or the reducing equivalents used for biosynthesis of molecules such as ethanol, butanol, isoprenoids, and fatty acids. As shown in Figure 1, hydrocarbon production is not limited to routes through acetyl-CoA. Pathways through pyruvate and G3P, for example, are also possible. However, the details of many of these pathways, including routes through $\mathrm{C} 5$ sugars, are yet to be determined. The next sections provide a high level look at a few of these routes.

\subsubsection{Higher alcohols}

Higher alcohols with a carbon number greater than two are potential advanced fuels. The higher the carbon number, the more compatible the alcohol is with the existing fuel infrastructure. In this report butanol is used as an example alcohol. Although butanol is not an aliphatic hydrocarbon, it is more infrastructure compatible than ethanol due to its lower water absorption and higher energy density (only $22 \%$ oxygen by weight vs. $35 \%$ for ethanol).

\section{Natural alcohol Pathways}

A well-known biochemical production process for butanol (along with ethanol and acetone) uses fermentation of sugars by Clostridium spp. However, because of butanol toxicity to the organism, the final titer is limited to $13-18 \mathrm{~g} / \mathrm{L}$. Ezeji et al. are studying alternative fermentation reactors to mitigate butanol toxicitiy (Ezeji 2005). Jiang et al.(2009) is manipulating biochemical pathways to produce less acetone. To reduce control and optimization limitations displayed by the native producer, the biosynthetic pathway for n-butanol was incorporated in engineered Eschericia coli (Yan 2009). This pathway, shown in Figure 4, is also capable of co-producing isopropanol.

\section{$\underline{\text { Ketoacid Elongation Pathways }}$}

As an alternative to alcohol fermentation through natural hosts, iso-butanol is being pursued through the pyruvate pathway (Shen 2008). Non-fermentive routes to C3-C8 alcohols, from 3-methyl-t-butanol to 2phenyl ethanol, using the 2-keto degradation pathway are being pursued by Atsumi and coworkers (Atsumi 2007, 2008). In general, at present, the alcohol yields decline as the carbon number rises: ethanol yield > butanol yield > pentanol yield (Lee 2008). 


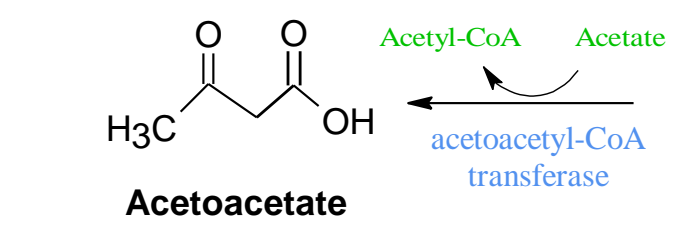

$\left.\begin{array}{l}\text { acetoacetate } \\ \text { decarboxylase }\end{array}\right\} \begin{aligned} & \mathrm{NADH} \\ & \mathrm{CO}_{2}+\mathrm{NAD}^{+}\end{aligned}$<smiles>CC(C)=O</smiles>

Acetone

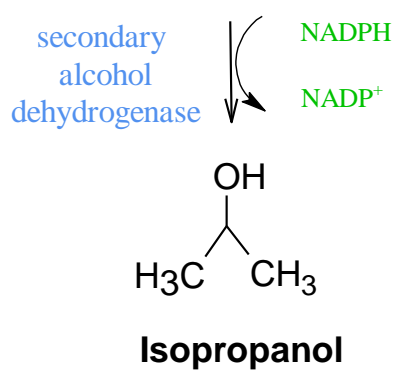

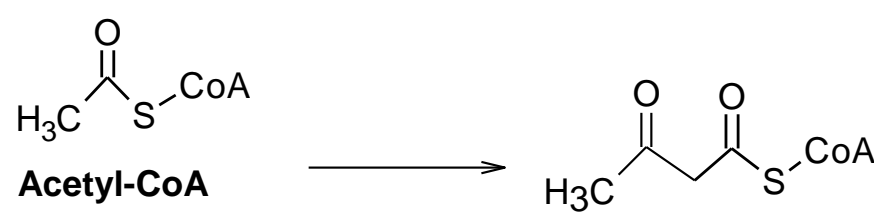

Acetoacetyl-CoA<smiles>CC(O)CC(=O)SCC(=O)O</smiles>

3-Hydroxy-butyryl-CoA

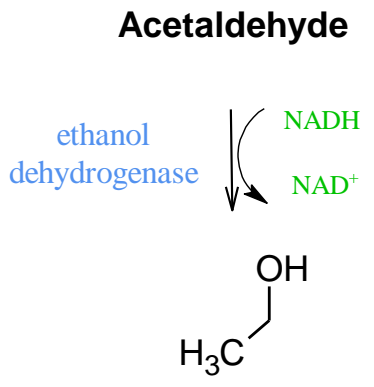

Ethanol

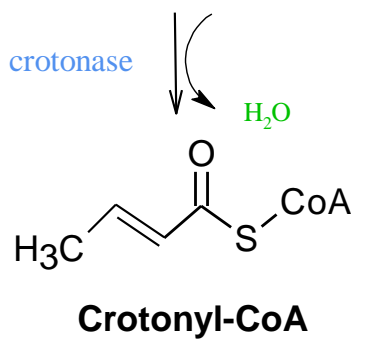

$$
\begin{gathered}
\text { butyryl-CoA } \\
\text { dehydrogenase }
\end{gathered}
$$

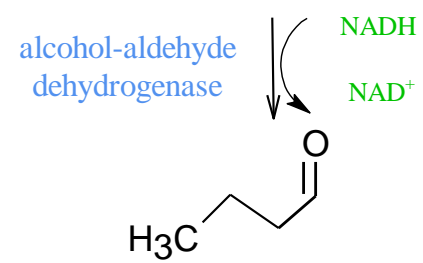

\section{Butyraldehyde}

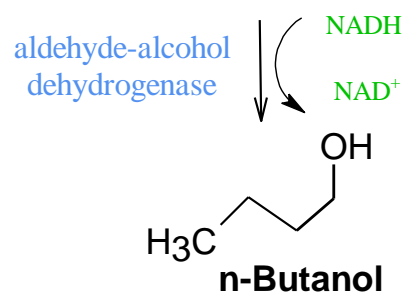

Figure 4. Biosynthesis of n-Butanol, Isopropanol, Acetone and Ethanol 


\subsubsection{Isoprenoids}

Isoprenoids belong to a class of molecules called lipids. Lipids are a very diverse group of naturally occurring molecules that form the structural part of cell membranes or are used by the organism as an energy source (Fahy 2005). Lipids tend to be highly reduced molecules and therefore have higher energy storage per carbon then most other molecules. Isoprenoids are general terms for a class of over 50,000 chemical compounds. Isoprene (2-methyl-1,3-butadiene) is the monomer unit for all isoprenoids and isopentenyl-diphosphate (IPP) is the universal biological pre-cursor for isoprenoid production. Several reviews of isoprenoids and engineered organisms have been published (Rodriguez 2002, Maury 2005, Chang 2006, Dembitsky 2006, Julsing 2007, Ajikumar 2008). The $\mathrm{C}_{5}$ compound IPP can be condensed to form longer chain isoprenoids of 10 to 40 carbons or more, as shown in Table 5 (Maury 2005). These higher molecular weight isoprenoids can potentially be tailored to be compatible replacements for conventional additives in jet-fuels and diesel fuels. Although isoprenoid biosynthesis is more energy intensive than ethanol formation, isoprenoids may be more suitable fuels or fuel additives. They have a higher energy content due to their low oxygen content (e.g., myrcene, $\mathrm{C}_{10} \mathrm{H}_{16}, 0 \%$ oxygen, or farnesol, $\mathrm{C}_{15} \mathrm{H}_{32} \mathrm{O}, 7 \%$ oxygen), and higher octane numbers because of the branched, cyclic or even aromatic nature of different isoprenoids. However, yields will be reduced as the molecule becomes more saturated and less oxygenated. Figure 5 shows isoprene, IPP and a representative hydrocarbon type isoprenoid, $\beta$ farnesene.

Table 5. Classification of Terpenoids Based on Number of Isoprene Units

\begin{tabular}{cccc}
\hline Class & Isoprene Units & Carbon Atoms & Formula \\
Monoterpenoids & 2 & 10 & $\mathrm{C}_{10} \mathrm{H}_{16}$ \\
Sesquiterpenoids & 3 & 15 & $\mathrm{C}_{15} \mathrm{H}_{24}$ \\
Diterpenoids & 4 & 20 & $\mathrm{C}_{20} \mathrm{H}_{32}$ \\
Sesterterpenoids & 5 & 25 & $\mathrm{C}_{25} \mathrm{H}_{40}$ \\
Triterpenoids & 6 & 30 & $\mathrm{C}_{30} \mathrm{H}_{48}$ \\
Tetraterpenoids & 8 & 40 & $\mathrm{C}_{40} \mathrm{H}_{64}$ \\
Polyterpenoids & $>8$ & $>40$ & $\left(\mathrm{C}_{5} \mathrm{H}_{8}\right)_{\mathrm{n}}$ \\
\hline
\end{tabular}<smiles>C=CC(=O)OC</smiles><smiles>C=C(C)CCOP(=O)(O)P(=O)(O)O</smiles><smiles>C=CC(=C)CCC=C(C)CCC=C(C)C</smiles>

Figure 5. Example Isoprenoids

\section{$\beta$-farnesene}


Isoprenoids are not limited to polymerization of IPP to branched products. Cyclic compounds, such as 2phenylethanol, can also be formed (Chang 2006). Farnesene is an example of an engineered outcome. Here, the introduction of the appropriate synthase enzymes allows extracellular production (Renninger 2008).

Two biosynthetic pathways exist for production of IPP and its isomer dimethyl allyl diphosphate (DMAPP). IPP is known to be produced by microorganisms through the mevalonic acid pathway (known as both MEV and MVA pathways), where three acetyl-CoA molecules are required to produce one mevalonate molecule which proceeds down the pathway to IPP. The MEV pathway as derived from Ladygina (2006), Renninger (2008), Yan (2009), Anthony (2009) and Kreamer (2010) is shown in Figure 6.
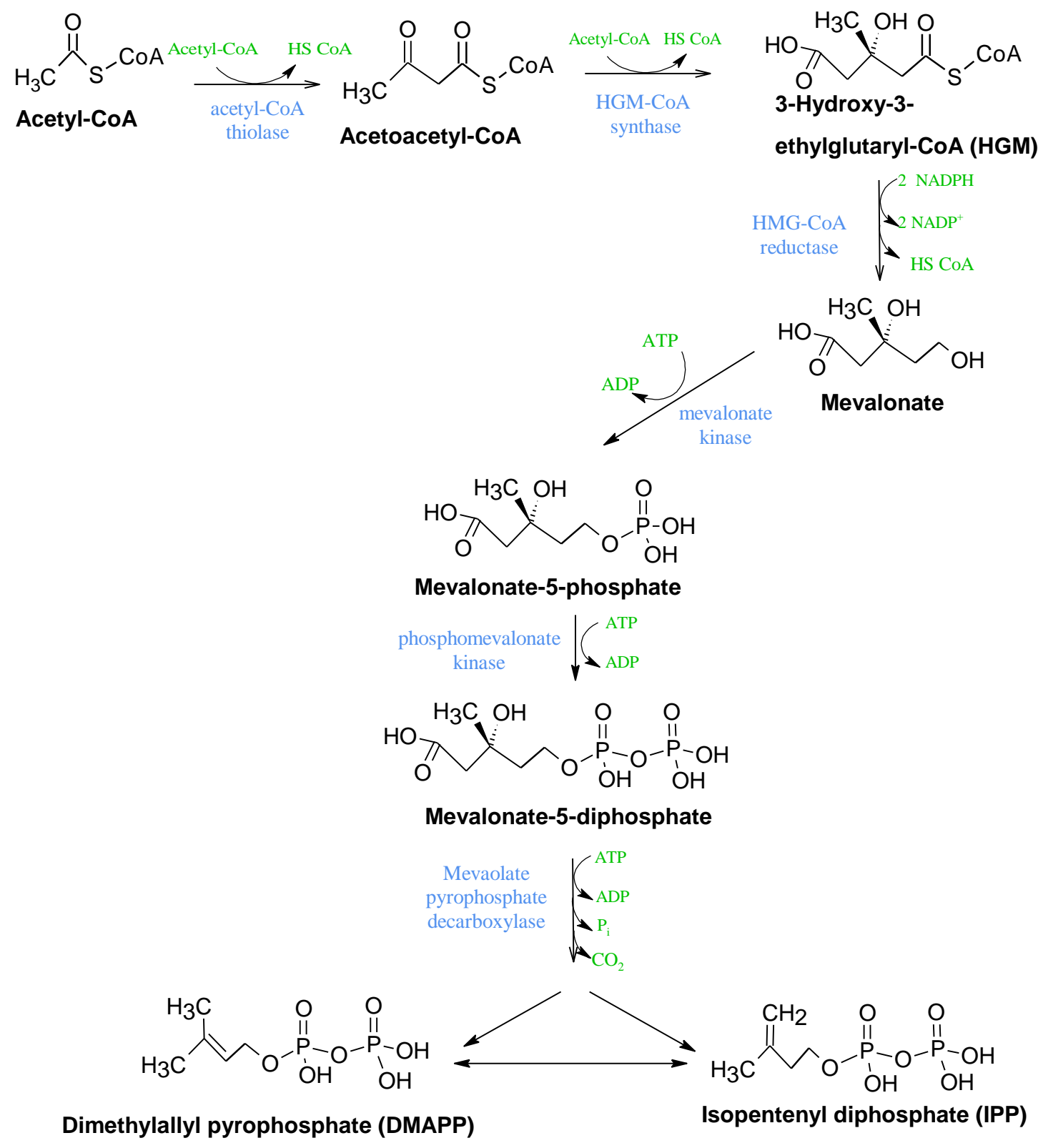

Figure 6. MEV Biosynthetic Pathway 
More recently, a non-mevalonate pathway called the MEP pathway (also known as the DXP pathway) named for the intermediate five carbon compound 2-methyl-erythritol-4-phosphate (MEP) was identified in bacteria and plant chloroplasts. In this pathway pyruvate and glyceraldehyde-3-phosphate serve as the initial metabolites instead of acetyl-CoA, and they are condensed to form MEP (Seemann 2002). The MEP pathway shown in Figure 7 is derived from Eisenriech (2004), Ladygina (2006), Yan (2009) and Kreamer (2010).
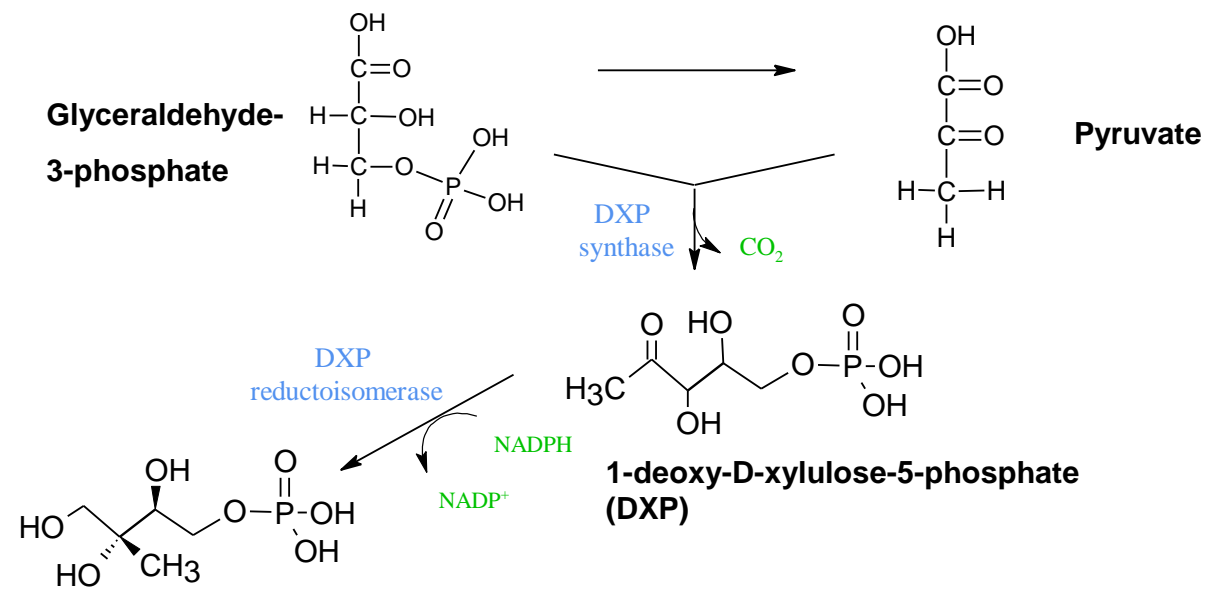

\section{2-C-Methyl-D-erythritol-4-phosphate}

(MEP)

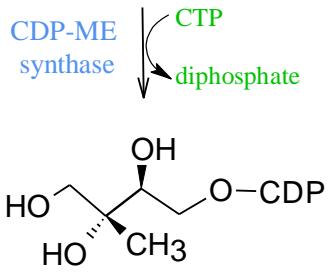

4-Diphosphocytidyl-

2-C-methylerithritol (CDP-ME)

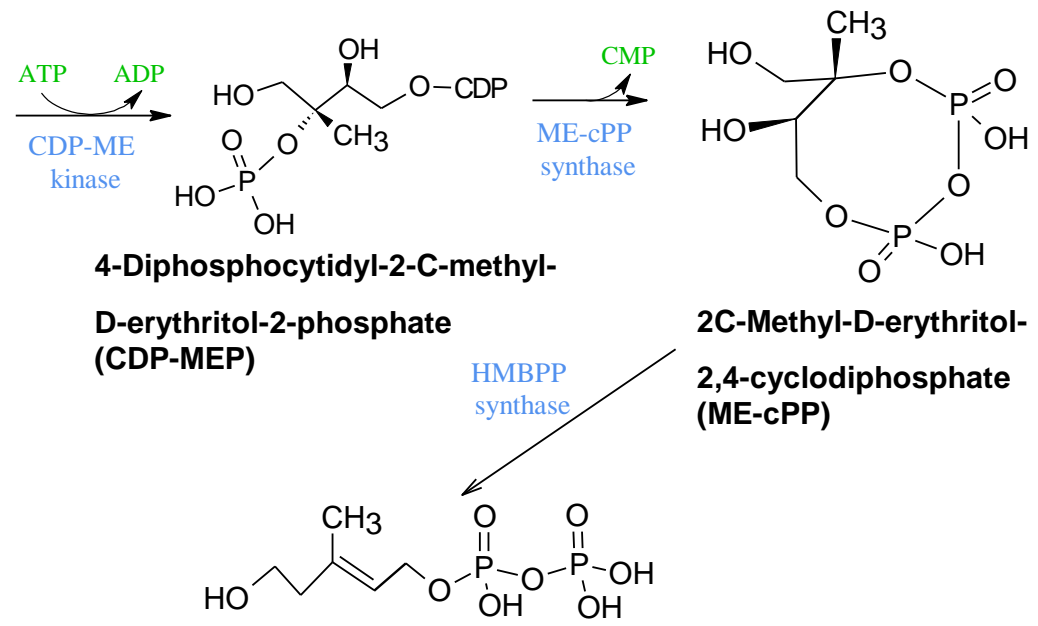

(E)-1-Hydroxy-2-methyl-butenyl-4-diphosphate (HMBPP)

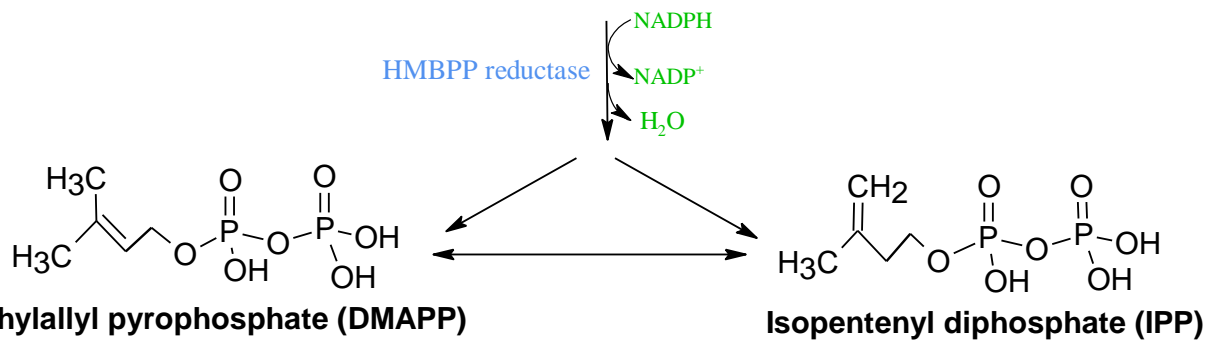

Figure 7. MEP Biosynthetic Pathway 
Only trace amounts of isoprenoids are naturally derived through either path, thus engineering the organism's natural production pathway will be required (Atsumi 2008). Daum (2009) reviews recent studies of the genes and enzymes related to bacterial isoprenoid biosynthesis that provide insights into these processes.

\subsubsection{Fatty Acids}

Fatty acids are also a type of lipid. Some of the best know lipids are molecules of long-standing interest called triacylglycerides (TAGs). TAGs are storage lipids consisting of an ester group between glycerol and three fatty acid molecules. The fatty acids typically range from $\mathrm{C}_{12}$ to $\mathrm{C}_{22}$ (predominantly $\mathrm{C}_{16}$ and $\mathrm{C}_{18}$ ) and are arranged in long tails unidirectional from the glycerol head of the TAG molecule. Current commercial sources of TAGs are vegetable oils from plants (e.g., corn, palm, sunflower and canola). Microbes such as green algae (e.g., Dunaliella salina), bacteria (e.g., engineered E. coli), and fungi (e.g., Mortierella alpina) can also produce TAGs. In current fuel applications, the TAGs are catalytically converted to fatty acids and transesterified with methanol to form fatty acid methyl esters (FAMEs), also known as biodiesel. Figure 8 shows TAG and fatty acid examples. "R" in this case detonates a hydrocarbon chain referred to as a fatty acid tail. Each tail typically contains 16, 18 or 20 carbons and zero to three carbon-carbon double bonds. Energy content of the TAG molecules is dependent on degree of hydrogen saturation which is depends on the number of double bonds found in the fatty acid tails (Robinson 2000).

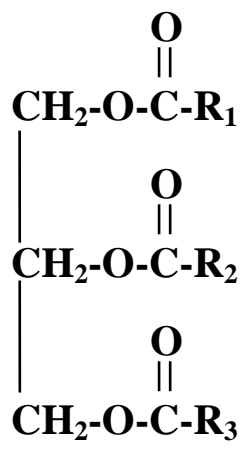

\section{where $\mathbf{R}=\mathbf{C x H y}$}

Figure 8. TAG Example

Palmitate is used here as an example compound. Palmitate, or palmitic acid, is a saturated $\mathrm{C}_{16}$ fatty acid, which is the precursor to many other types of fatty acids found to be produced by microorganisms and plants. The pathway for palmitate production from glucose, based on the fatty acid synthesis pathway found in most organisms, is shown in Figure 9. The fatty acid biosynthesis mechanism is dependent upon chain lengthening thiol-esters of a low-molecular weight protein called acyl carrier protein (ACP). Figure 9 was adapted from Magnuson (1993), Berg (2002), Yan (2009), and Murley (2009). 


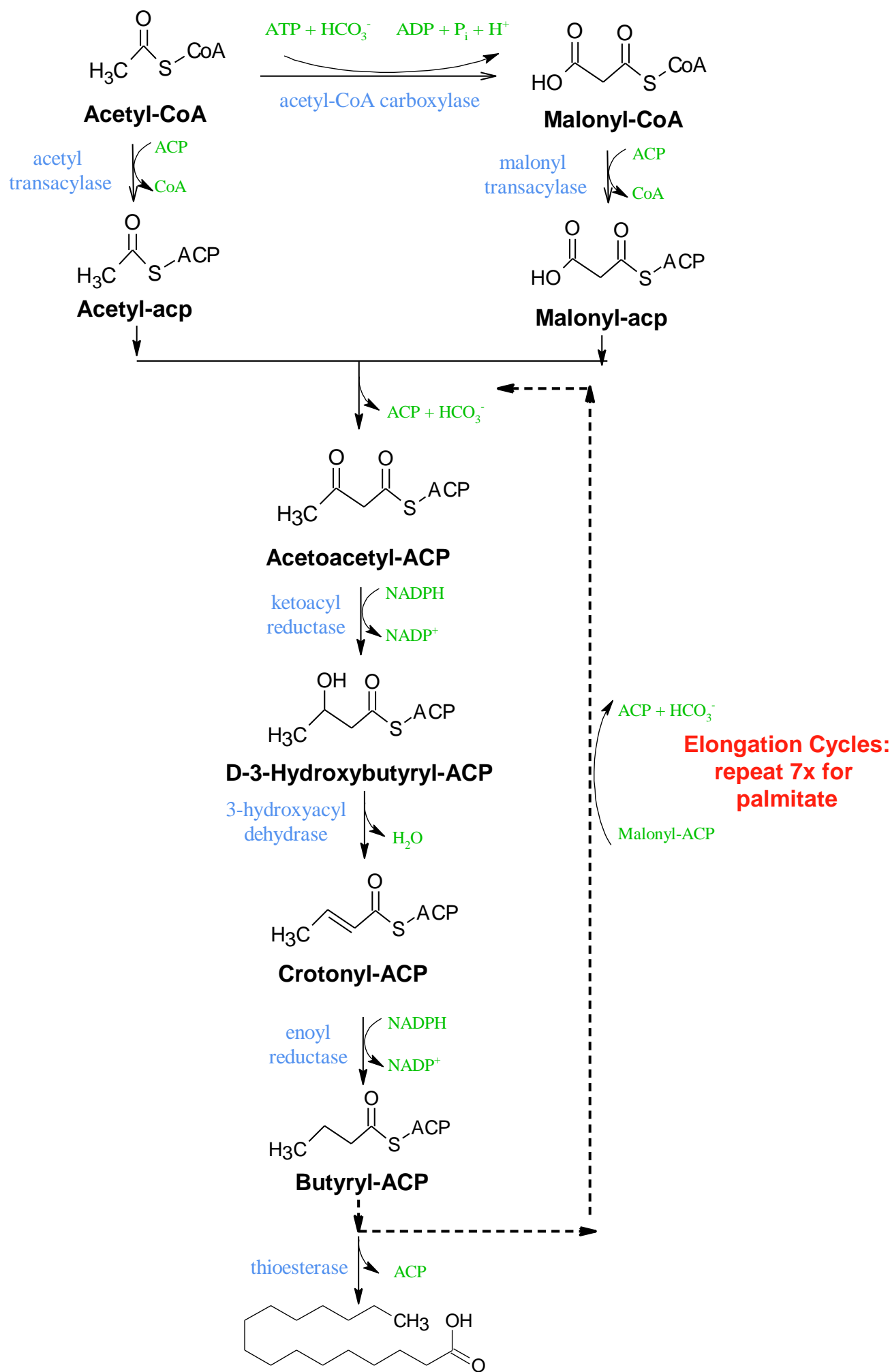

Palmitate

Figure 9. Biosynthesis of Fatty Acids 
Biosynthesis of fatty acids requires fixed carbon in the form of acetyl-CoA and malonyl-CoA, and considerable amounts of reducing equivalents in the form of NADPH (the cofactor that carries electron pairs for biosynthetic reactions). In heterotrophic organisms, such as bacteria and fungi, this required reducing energy and carbon is derived from the oxidation of glucose or other sugars with the concomitant formation of NADPH and acetyl-CoA. In phototrophs (plants and algae), photons from sunlight provide the energy for the generation of reducing equivalents and the fixation of carbon in the process known as photosynthesis

The biochemical pathway shown in Figure 9 and the accompanying stoichiometry for the net reactions are used to determine the theoretical yield of palmitate as discussed in the next section. Thus, in order to produce near theoretical yield of palmitate from glucose, there needs to be an emphasis on maximizing the availability of the necessary biochemical components within the microorganism.

In order to form fatty acids, and subsequently TAGs, the organism requires an excess supply of energy which in turn signals activation of the lipid synthesis pathway as a means to store the energy as fixed carbon. Organisms use glycolysis to supply acetyl-CoA. However a source of chemical energy to drive the reduction, and hence formation of lipids, is needed and comes in the form of NADPH. The pentose phosphate pathway (not shown) is used to supply the reducing energy needed in the form of NADPH. This discussion points out a common theme in production pathways of bio-hydrocarbons: in order to produce a highly reduced product, such as palmitic acid $\left(\mathrm{C}_{16} \mathrm{H}_{32} \mathrm{O}_{2}, 12 \%\right.$ oxygen by weight), from a highly oxygenated substrate, such as glucose $\left(\mathrm{C}_{6} \mathrm{H}_{12} \mathrm{O}_{6}, 53 \%\right.$ oxygen by weight), deoxygenation and reduction must occur. The stoichiometry of this net gain in hydrogen and loss of oxygen requires considerable formation of carbon dioxide and sometimes water. It is also possible to biochemically produce alkanes from fatty acids through the decaboxylase pathway. This pathway relies on a reaction that produces an alkane directly from an aldehyde precursor (Kreamer 2010). Understanding the details of this pathway will be useful in developing efficient processes.

As previously mentioned biologically, lipid bi-layers make up the cell membrane walls of organisms. In addition to this, a small number of organisms can also accumulate oils within the cell. These are known as oleaginous organisms, and the oil is referred to as Single Cell Oil (SCO) (Ratledge 2004). Specific yeasts and fungi are among some of the better known oleaginous organisms capable of storing up to $70 \%$ of their weight as lipid. The oil accumulation is the result of an unbalanced metabolism function when excess carbon with a limited amount of nutrient (nitrogen for example) is found in the production media. As the organism grows, the limiting nutrient is depleted, but the organism still takes in carbon which is then channeled into lipid synthesis. This results in a buildup of oil within the cell. In non-oleaginous organisms, the carbon is diverted into polysaccharides, and thus oil accumulation is less than $10 \%$ (Ratledge 2004). Chen (Chen 2009) screened oleaginous yeast strains tolerant to lignocellulosic degradation. Ratledge (Ratledge 2004, 2008) and Meng (Meng 2009) provide reviews of SCOs. Wynn (Wynn 2001) suggests a mechanism for storage lipid accumulation in oleaginous filamentous fungi.

Producing large extracellular lipid molecules will require modified organisms. The possible means for this may be by using transporter proteins or by diffusion through the cell wall. 


\subsubsection{Polyketide Pathway}

Polyketides have long had useful therapeutic value as antibiotics, immunosuppressants and antitumor drugs. They are also a versatile source of novel compounds (Shen 2003). Polyketides are secondary metabolites formed by bacteria, fungi, plants and animals. Many polyketides arise from the decarboxylative condensation of malonyl-CoA derived extender units and grow in a similar fashion to fatty acids using ACP, but without the dehydration and reduction steps. They cover a range of molecules such as small aromatics, polynuclear aromatics, and lipid like structures. Polyketides make a good precursor to longer fuel molecules. A number of reviews describe the various types of polyketide synthases (PKS) (Khosla 1999, Shen 2003 and Hertwick 2009). Table 6 is taken from Hertwick (2009) with the addition of example products.

Table 6. Polyketide Summary (Hertwick 2009)

\begin{tabular}{|c|c|c|c|}
\hline PKS Type & Building Blocks & Organisms & Examples \\
\hline $\begin{array}{l}\text { Type I (modular - } \\
\text { non-iterative) }\end{array}$ & $\begin{array}{l}\text { ACP, various extender units, } \\
\text { mainly malonyl-CoA, } \\
\text { methylmalonyl-CoA }\end{array}$ & bacteria, (protists) & $\begin{array}{l}\text { erythromycin, } \\
\text { rapamycin }\end{array}$ \\
\hline Type I (iterative) & $\begin{array}{l}\text { ACP, only malonyl-CoA } \\
\text { extenders }\end{array}$ & $\begin{array}{l}\text { mainly fungi, some } \\
\text { bacteria }\end{array}$ & $\begin{array}{l}\text { 6-methylsalicylic acid, } \\
\text { lovastatin, aflatoxin }\end{array}$ \\
\hline Type II (iterative) & $\begin{array}{l}\text { ACP, only malonyl-CoA } \\
\text { extenders }\end{array}$ & exclusively bacteria & $\begin{array}{l}\text { actinorhodin, } \\
\text { doxorubicin, } \\
\text { tetracenomycin }\end{array}$ \\
\hline Type III (iterative) & $\begin{array}{l}\text { Acyl-CoA, only malonyl-CoA } \\
\text { extenders }\end{array}$ & $\begin{array}{l}\text { mainly plants, some } \\
\text { bacteria and fungi }\end{array}$ & naringenin chalcone \\
\hline PKS-NRPS ${ }^{1}$ hybrid & $\begin{array}{l}\mathrm{ACP} \text {, malonyl-CoA, amino } \\
\text { acids }\end{array}$ & $\begin{array}{l}\text { bacteria (modular), } \\
\text { fungi (iterative) }\end{array}$ & salinosporamide-A \\
\hline
\end{tabular}

Type I iterative are smaller molecules produced mostly by fungi, such as aflatoxin, a polyketide found in peanut butter. Type II polyketides are developed by iterative systems (analogous to fatty acid development). Type III molecules are biosynthesized by exceptionally large, multifunctional proteins. PKS-NPRS hybrids are the result of Type I modules linked to nonribosomal peptide synthetase modules.

Development of polyketide pathways for alternative fuel production will have challenges comparable to the Fatty Acid and Isoprenoid pathways. Feasibility of all these routes is dependent on high production titers and reduced costs. Development of the pathway details for the various types of PKSs was not attempted for this report, but should be determined for future work. Examples of each PKS type are shown in Figure 10. 


\section{Type I (iterative): aflatoxin B2}<smiles>COc1cc2c(C3CCOC3OC)c3c1CCC3C(=O)O2</smiles>

\section{Type I (modular): rapamycin}

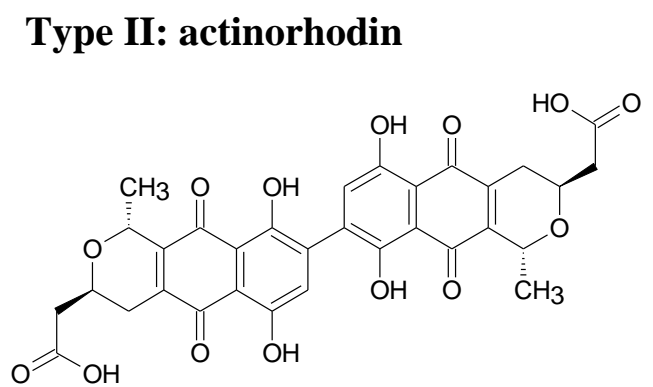

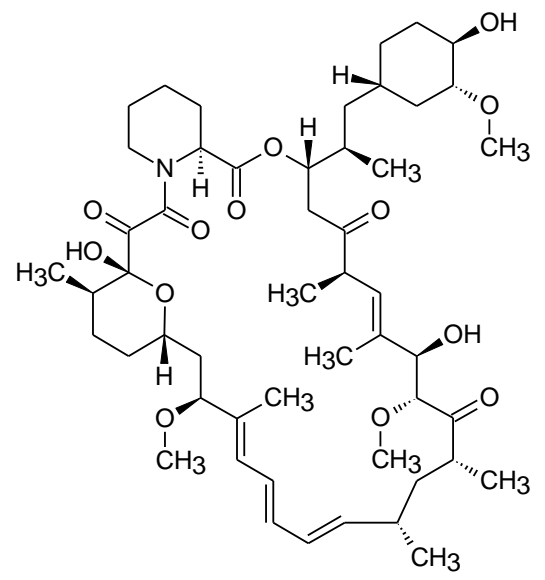

\section{Type III: naringenin chalcone}<smiles>O=C1CC(c2ccccc2)Oc2cc(O)cc(O)c21</smiles>

\section{PKS/NRPS hybrid:}

\section{salinosporamide A}

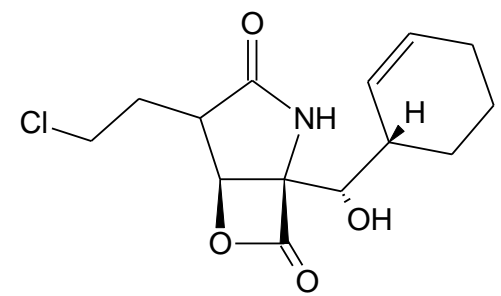

Figure 10. Polyketide Molecule Examples

\subsubsection{Theoretical Fuel Selectivity}

Stoichiometric equations give a theoretical upper limit as to how much product might be obtained from a carbon substrate. Glucose was chosen as the model feedstock for this study, mainly because it is a broadly available carbon source easily metabolized by the majority of microorganisms. The stoichiometry presented here is based on published biochemical pathways (Lehninger 1978, Metzler 2001) in addition to the sources used for Figures 2, 3, 4, 6, 7 and 9. Ethanol is included for comparison purposes. The details for these reactions are as follows (using the abbreviations from the aforementioned figures): 
Ethanol Stoichiometry Net: $\mathrm{C}_{6} \mathrm{H}_{12} \mathrm{O}_{6}+2 \mathrm{ADP}+2 \mathrm{P}_{i} \rightarrow 2 \mathrm{C}_{2} \mathrm{H}_{5} \mathrm{OH}+2 \mathrm{CO}_{2}+2 \mathrm{H}_{2} \mathrm{O}+2 \mathrm{ATP}$

1. $\mathrm{C}_{6} \mathrm{H}_{12} \mathrm{O}_{6}+\mathrm{ATP}$

2. $\mathrm{G} 6 \mathrm{P}$

3. $\mathrm{F} 6 \mathrm{P}+\mathrm{ATP}$

4. $2 \mathrm{G} 3 \mathrm{P}+2 \mathrm{NAD}^{+}+2 \mathrm{P}_{i}+4 \mathrm{ADP}$

5. 2 Pyruvate $+2 \mathrm{CoA}+2 \mathrm{NAD}^{+}$

6. 2 Acetyl-CoA $+2 \mathrm{NADH}+2 \mathrm{H}^{+}$

7. 2 Acetaldehyde $+2 \mathrm{NADH}+2 \mathrm{H}^{+}$ $\rightarrow \mathrm{G} 6 \mathrm{P}+\mathrm{ADP}$

$\rightarrow$ F6P

$\rightarrow 2 \mathrm{G3P}+\mathrm{ADP}$

$\rightarrow 2$ Pyruvate $+2 \mathrm{NADH}+2 \mathrm{H}^{+}+4 \mathrm{ATP}+2 \mathrm{H}_{2} \mathrm{O}$

$\rightarrow 2$ Acetyl-CoA $+2 \mathrm{CO}_{2}+2 \mathrm{NADH}+2 \mathrm{H}^{+}$

$\rightarrow 2$ Acetaldehyde $+2 \mathrm{NAD}^{+}+2 \mathrm{CoA}$

$\rightarrow 2 \mathrm{NAD}^{+}+2 \mathrm{C}_{2} \mathrm{H}_{5} \mathrm{OH}$

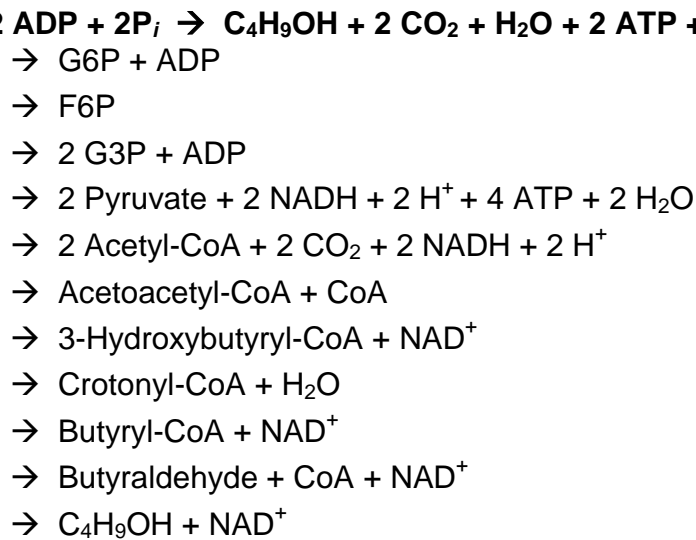

Isoprenoid sub-unit (IPP/DMAPP)-MEV Pathway Stoichiometry

Net: $1.5 \mathrm{C}_{6} \mathrm{H}_{12} \mathrm{O}_{6}+6 \mathrm{NAD}^{+}+2 \mathrm{NADPH}+2 \mathrm{P}_{i} \rightarrow \mathrm{C}_{5} \mathrm{H}_{9} \mathrm{OH}-\mathrm{PP}+4 \mathrm{CO}_{2}+2 \mathrm{H}_{2} \mathrm{O}+6 \mathrm{NADH}+6 \mathrm{H}^{+}+2 \mathrm{NADP}^{+}$

1. $1.5 \mathrm{C}_{6} \mathrm{H}_{12} \mathrm{O}_{6}+1.5 \mathrm{ATP}$

2. $1.5 \mathrm{G} 6 \mathrm{P}$

3. 1.5 F6P + 1.5 ATP

4. $3 \mathrm{G} 3 \mathrm{P}+3 \mathrm{NAD}^{+}+6 \mathrm{ADP}+3 \mathrm{P}_{i}$

5. 3 Pyruvate $+3 \mathrm{CoA}+3 \mathrm{NAD}^{+}$

6. 3 Acetyl-CoA

7. Acetoacetyl-CoA + Acetyl-CoA $+\mathrm{H}_{2} \mathrm{O}$

8. $\mathrm{HMG}-\mathrm{CoA}+2 \mathrm{NADPH}+2 \mathrm{H}^{+}$

9. $\mathrm{C}_{6} \mathrm{H}_{10} \mathrm{O}_{4}+\mathrm{ATP}$

10. $\mathrm{M} 5 \mathrm{P}+\mathrm{ATP}$

11. $M 5 D P+A T P$ $\rightarrow 1.5 \mathrm{G} 6 \mathrm{P}+1.5 \mathrm{ADP}$

$\rightarrow 1.5 \mathrm{~F} 6 \mathrm{P}$

$\rightarrow 3 \mathrm{G} 3 P+1.5 \mathrm{ADP}$

$\rightarrow 3$ Pyruvate +6 ATP $+3 \mathrm{NADH}+3 \mathrm{H}^{+}+3 \mathrm{H}_{2} \mathrm{O}$

$\rightarrow 3$ Acetyl-CoA $+3 \mathrm{CO}_{2}+3 \mathrm{NADH}+3 \mathrm{H}^{+}$

$\rightarrow$ Acetoacetyl-CoA + CoA + Acetyl-CoA

$\rightarrow \mathrm{HMG}-\mathrm{CoA}+\mathrm{CoA}$

$\rightarrow \mathrm{C}_{6} \mathrm{H}_{10} \mathrm{O}_{4}+2 \mathrm{NADP}^{+}+\mathrm{CoA}$

$\rightarrow \mathrm{M} 5 \mathrm{P}+\mathrm{ADP}$

$\rightarrow \mathrm{M} 5 \mathrm{DP}+\mathrm{ADP}$

$\rightarrow \mathrm{C}_{5} \mathrm{H}_{9} \mathrm{OH}-\mathrm{PP}+\mathrm{CO}_{2}+\mathrm{ADP}+\mathrm{P}_{i}$

Isoprenoid sub-unit (IPP/DMAPP)-MEP Pathway Stoichiometry

Net: $\mathrm{C}_{6} \mathrm{H}_{12} \mathrm{O}_{6}+\mathrm{NAD}^{+}+2 \mathrm{NADPH}+2 \mathrm{H}^{+}+\mathrm{ATP}+\mathrm{CTP}+\mathrm{P}_{i} \rightarrow \mathrm{C}_{5} \mathrm{H}_{9} \mathrm{OH}-\mathrm{PP}+\mathrm{CO}_{2}+2 \mathrm{H}_{2} \mathrm{O}+\mathrm{NADH}+\mathrm{H}^{+}+2 \mathrm{NADP}+{ }^{+} \mathrm{ADP}+\mathrm{CMP}^{+}$

1. $\mathrm{C}_{6} \mathrm{H}_{12} \mathrm{O}_{6}+\mathrm{ATP}$

2. $\mathrm{G} 6 \mathrm{P}$

3. $F 6 P+A T P$

4. $2 \mathrm{G} 3 \mathrm{P}+\mathrm{NAD}^{+}+2 \mathrm{ADP}+\mathrm{P}_{i}$

5. Pyruvate $+\mathrm{G} 3 \mathrm{P}$

6. $\mathrm{DXP}+\mathrm{NADPH}+\mathrm{H}^{+}$

7. $\mathrm{MEP}+\mathrm{CTP}$

8. CDP-ME + ATP

9. CDP-MEP

10. Me-CPP

11. $\mathrm{HMBPP}+\mathrm{NADPH}+\mathrm{H}^{+}$ $\rightarrow \mathrm{G} 6 \mathrm{P}+\mathrm{ADP}$

$\rightarrow \mathrm{F} 6 \mathrm{P}$

$\rightarrow 2 \mathrm{G3P}+\mathrm{ADP}$

$\rightarrow \mathrm{G} 3 \mathrm{P}+$ Pyruvate $+2 \mathrm{ATP}+\mathrm{NADH}+\mathrm{H}^{+}+\mathrm{H}_{2} \mathrm{O}$

$\rightarrow \mathrm{DXP}+\mathrm{CO}_{2}$

$\rightarrow \mathrm{MEP}+\mathrm{NADP}^{+}$

$\rightarrow$ CDP-ME $+\mathrm{PP}_{i}$

$\rightarrow$ CDP-MEP + ADP

$\rightarrow \mathrm{Me}-\mathrm{CPP}+\mathrm{CMP}$

$\rightarrow \mathrm{HMBPP}$

$\rightarrow \mathrm{C}_{5} \mathrm{H}_{9} \mathrm{OH}-\mathrm{PP}+\mathrm{NADP}^{+}+\mathrm{H}_{2} \mathrm{O}$ 
Fatty Acid Pathway Stoichiometry

Net: $4 \mathrm{C}_{6} \mathrm{H}_{12} \mathrm{O}_{6}+2 \mathrm{NAD}^{+}+7 \mathrm{ATP} \rightarrow \mathrm{CH}_{3}\left(\mathrm{CH}_{2}\right)_{14} \mathrm{COOH}+2 \mathrm{NADH}+2 \mathrm{H}^{+}+7 \mathrm{ADP}+7 \mathrm{P}_{i}+8 \mathrm{CO}_{2}+6 \mathrm{H}_{2} \mathrm{O}$

1. $4 \mathrm{C}_{6} \mathrm{H}_{12} \mathrm{O}_{6}+4 \mathrm{ATP}$

$\rightarrow 4 \mathrm{G} 6 \mathrm{P}+4 \mathrm{ADP}$

2. $4 \mathrm{G} 6 \mathrm{P}$

$\rightarrow 4 \mathrm{~F} 6 \mathrm{P}$

3. $4 \mathrm{~F} 6 \mathrm{P}+4 \mathrm{ATP}$

$\rightarrow 8 \mathrm{G} 3 \mathrm{P}+4 \mathrm{ADP}$

4. $8 \mathrm{G} 3 \mathrm{P}+8 \mathrm{ADP}+8 \mathrm{NAD}^{+}$

$\rightarrow 8$ Pyruvate +8 ATP $+8 \mathrm{NADH}+8 \mathrm{H}^{+}$

5. 8 Pyruvate $+8 \mathrm{CoA}+8 \mathrm{NAD}^{+}$

$\rightarrow 8$ Acetyl-CoA $+8 \mathrm{CO}_{2}+8 \mathrm{NADH}+8 \mathrm{H}^{+}$

6. 7 Acetyl-CoA $+7 \mathrm{CO}_{2}+7$ ATP

$\rightarrow 7$ Malonyl-CoA + $7 \mathrm{ADP}+7 \mathrm{P} i$

7. $14 \mathrm{NADH}+14 \mathrm{NADP}^{+}$

$\rightarrow 14 \mathrm{NADPH}+14 \mathrm{NAD}^{+}$

8. Acetyl-CoA+7malonyl-CoA+14 NADPH+14 $\mathrm{H}^{+} \rightarrow \mathrm{CH}_{3}\left(\mathrm{CH}_{2}\right){ }_{14} \mathrm{COOH}+7 \mathrm{CO}_{2}+8 \mathrm{CoA}+4 \mathrm{NADP}^{+}+6 \mathrm{H}_{2} \mathrm{O}$

The net stoichiometric equations are summarized in Table 7. The theoretical selectivity does not include carbon needed for cell growth. Note that for the two isoprenoid pathways, the MEP pathway has higher theoretical carbon selectivity than the MEV pathway, but requires more energy (in the form of ATP) and has fewer $\mathrm{H}^{+}$that can subsequently be used for ATP generation.

Table 7. Stoichiometry, Theoretical Selectivity and Yields

\begin{tabular}{|c|c|c|}
\hline $\begin{array}{l}\text { Products } \\
\text { from glucose }\end{array}$ & Reactions & $\begin{array}{l}\text { Carbon Selectivity } \\
\text { Product : } \mathrm{CO}_{2}\end{array}$ \\
\hline Ethanol & $\begin{array}{l}\mathrm{C}_{6} \mathrm{H}_{12} \mathrm{O}_{6}+2 \mathrm{ADP}+2 \mathrm{P}_{i} \rightarrow 2 \mathrm{C}_{2} \mathrm{H}_{5} \mathrm{OH}+2 \mathrm{CO}_{2}+2 \mathrm{H}_{2} \mathrm{O}+2 \mathrm{ATP} \\
\text { Example: Saccharomyces cerevisae (Metzler 2001) }\end{array}$ & $67 \%: 33 \%$ \\
\hline n-Butanol & $\begin{array}{l}\mathrm{C}_{6} \mathrm{H}_{12} \mathrm{O}_{6}+2 \mathrm{ADP}+2 \mathrm{P}_{i} \rightarrow \mathrm{C}_{4} \mathrm{H}_{9} \mathrm{OH}+2 \mathrm{CO}_{2}+\mathrm{H}_{2} \mathrm{O}+2 \mathrm{ATP}+\mathrm{CoA} \\
\text { Example: Clostridium acetobutylicum (Ezeji 2005) }\end{array}$ & $67 \%: 33 \%$ \\
\hline $\begin{array}{l}\text { Isopentenyl } \\
\text { diphosphate } \\
\text { (MEV Pathway) }\end{array}$ & $\begin{array}{l}1.5 \mathrm{C}_{6} \mathrm{H}_{12} \mathrm{O}_{6}+6 \mathrm{NAD}^{+}+2 \mathrm{NADPH}+2 \mathrm{P}_{i} \rightarrow \mathrm{C}_{5} \mathrm{H}_{9} \mathrm{OH}-\mathrm{PP}+4 \mathrm{CO}_{2}+ \\
2 \mathrm{H}_{2} \mathrm{O}+6 \mathrm{NADH}+6 \mathrm{H}^{+}+2 \mathrm{NADP}^{+} \\
\text {Examples: staphylococci, streptococci, fungi (Maury 2005) }\end{array}$ & $56 \%: 44 \%$ \\
\hline $\begin{array}{l}\text { Isopentenyl } \\
\text { diphosphate } \\
\text { (MEP Pathway) }\end{array}$ & $\begin{array}{l}\mathrm{C}_{6} \mathrm{H}_{12} \mathrm{O}_{6}+\mathrm{NAD}^{+}+2 \mathrm{NADPH}+2 \mathrm{H}^{+}+\mathrm{ATP}+\mathrm{CTP}+\mathrm{P}_{i} \rightarrow \mathrm{C}_{5} \mathrm{H}_{9} \mathrm{OH}- \\
\mathrm{PP}+\mathrm{CO}_{2}+2 \mathrm{H}_{2} \mathrm{O}+\mathrm{NADH}+\mathrm{H}^{+}+2 \mathrm{NADP}+\mathrm{ADP}+\mathrm{CMP} \\
\text { Examples: } \text {. coli }(\text { Mauri 2005) Mycobacterium tuberculosis } \\
\text { (Ladygina 2006) }\end{array}$ & $83 \%: 17 \%$ \\
\hline $\begin{array}{l}\text { Palmitate } \\
\text { (Fatty Acid } \\
\text { Pathway) }\end{array}$ & $\begin{array}{l}4 \mathrm{C}_{6} \mathrm{H}_{12} \mathrm{O}_{6}+2 \mathrm{NAD}^{+}+7 \mathrm{ATP} \rightarrow \mathrm{CH}_{3}\left(\mathrm{CH}_{2}\right)_{14} \mathrm{COOH}+2 \mathrm{NADH}+2 \\
\mathrm{H}^{+}+7 \mathrm{ADP}+7 \mathrm{P}_{i}+8 \mathrm{CO}_{2}+6 \mathrm{H}_{2} \mathrm{O} \\
\text { Examples: E. coli (Magnuson 1993) }\end{array}$ & $67 \%: 33 \%$ \\
\hline
\end{tabular}

The theoretical yield can never be achieved, much less approached, if the carbon source is also the source for initial growth of the organism (microbial biomass accumulation and biocatalyst synthesis). These are but a cursory example of the type of information needed to develop more efficient microbial processes. Detailed metabolic equations for each pathway should be generated to help assess the trade-offs between 
organism energy needs and desired product formation. This is particularly true for iterative pathways for isoprenoids, fatty acids and polyketides.

\subsubsection{Fuel Production}

Figure 11 illustrates where the bio-based hydrocarbons discussed earlier might fit into the existing fuel pool. Figure 11 plots boiling points against carbon number of the conventional fuels shown in Table 1 . While boiling points and carbon numbers do not exactly correlate in gasoline, diesel and jet, they do so sufficiently enough to show general trends for the proposed bio-based fuels. Superimposed on this plot are the boiling points of several of the proposed bio-fuels discussed earlier as a way of illustrating where those fuels might fit into the existing conventional fuel mix.

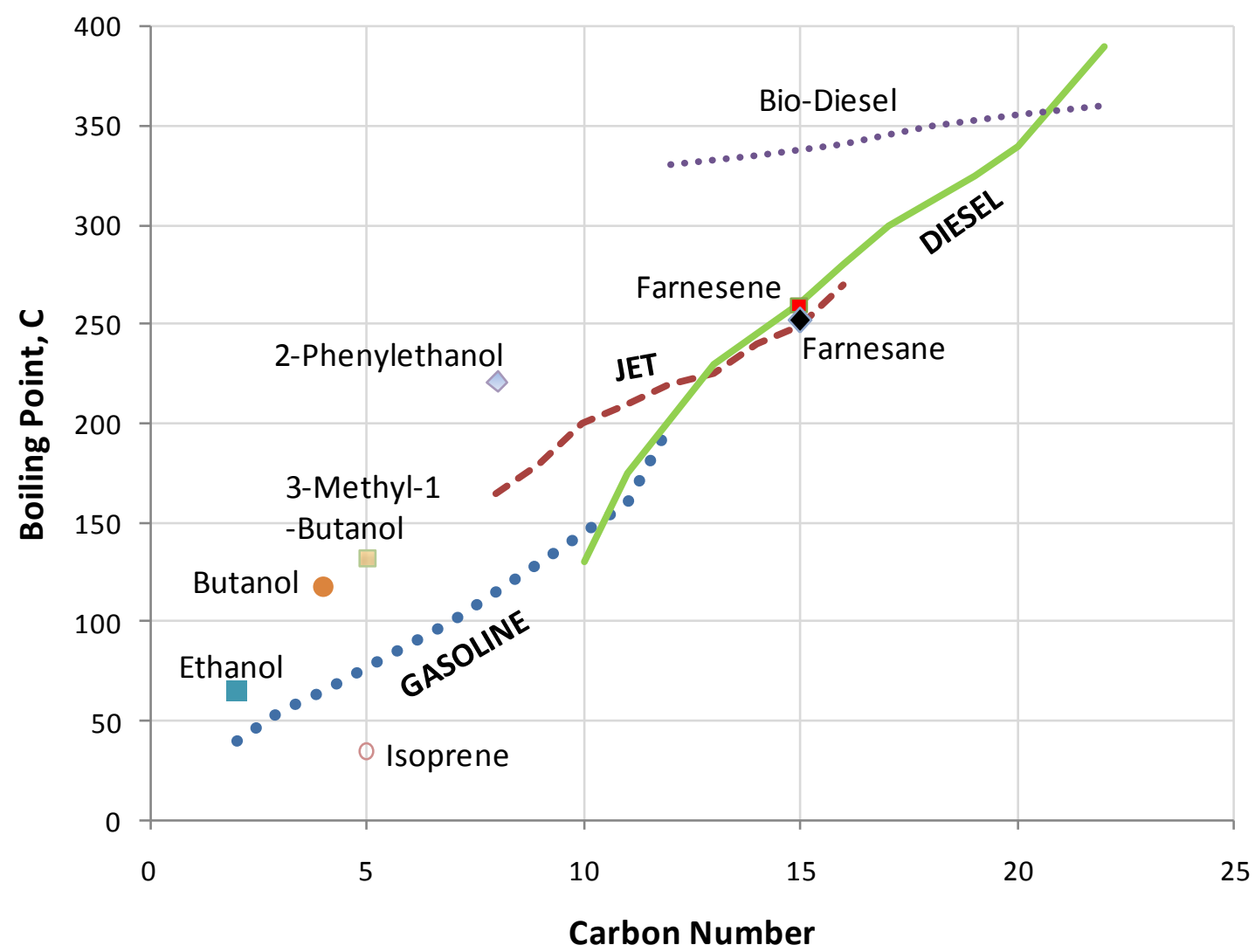

Figure 11. Conventional and Biofuels Approximate Volatility and Carbon Number

Lower alcohols such as butanol and methyl-butanol are in the gasoline range. The fuel synthesis for butanol is similar to that for ethanol. Butanol is suitable for ground transportation use as a blendstock with conventional gasoline however it is not a hydrocarbon and therefore not completely compatible with existing infrastructure. Blends up to $16 \%$ by volume are allowed in the US, as opposed to $10 \%$ maximum for ethanol (Butamax 2010). Butanol is not suitable for use as an aviation fuel due to its low heating value relative to a pure hydrocarbon (Hileman 2009). Even through butanol may have less hygroscopic issues than ethanol, it is still cannot be classified as a "drop in" replacement. 
Isoprene and its related compounds require further processing to make a finished fuel. For the production of farnesane, a diesel equivalent, the farnesene product is treated over conventional hydrogenation catalyst to saturate the alkene bonds to alkanes (Renninger 2008). 2-phenylethanol, with a boiling point of $221^{\circ} \mathrm{C}$, is at the lower end of the diesel range. Given that its aromatic nature gives it poor cetane qualities, this compound would likely require finishing hydrogenation to convert it to ethylbenzene, a good octane enhancer for gasoline. Also, given that conventional fuels span a boiling range and a mix of aromatics and normal and isoparaffins, it seems unlikely that a single molecule product could completely replace conventional fuel, and would serve at best as a blend-stock.

Oil production through single cell organism (SCO) pathways requires lysing the cell to release the oil which is an expensive processing step. It is more desirable to have the oil move through the cell wall to the fermentation broth such as through the use of transport proteins that erode the cell walls. SCOs are fuel precursors and require subsequent processing to produce a finished fuel. The bio-diesel shown on the plot is derived from oleaginous organism oils that have been esterified, similar to vegetable oil conversion to bio-diesel. This type of fuel would be comparable to vegetable oil based biodiesel and could be used as a blend stock for road diesel. Another processing method is to hydro-treat the SCO to produce completely deoxygenated hydrocarbons for blending into diesel (Holmgren 2007). This type of fuel could be used for jet fuel as well as road diesel. However, the source of the hydrogen needs to be renewable in order for the product to be considered an advanced fuel. In short, a wide range of molecules is possible, but each have their own processing issues to be overcome before they are commercially ready.

Figure 12 shows the conversion steps involved in conventional refining of crude to gasoline and the many possible pathways via biomass processing. It is notable that conventional refining of crude oil to gasoline involves many separate conversion steps:

- Isomerization to form branched species out of linear hydrocarbons,

- Alkylation to produce branched C8 hydrocarbons from C4's,

- Reforming to produce aromatic species from naphtha,

- Hydrocracking, catalytic cracking and coking to produce lighter material from the high boiling portion of crude oil.

Bio-refineries will also need to have multiple conversion steps in order to produce fuels that match existing fuels. This is shown on the right side of Figure 12. The fuel compositions are taken from "The Composition of Petroleum Mixtures, Vol 2" (Potter 1998). Biomass conversion to alcohols, acids and olefinic materials can be processed in many ways to produce all parts of the desired fuel. Such conversion steps include oligomerization, dehydration, alkylation, hydrogenation and condensation.

Figure 13 and Figure 14 show conventional and potential bio-based routes to jet fuel and diesel respectively. Similar to the diagram for gasoline, both jet fuel and diesel production in a conventional refinery involves multiple steps and are comprised of multiple compounds. Biorefineries producing these types of fuels will also likely have more than a single conversion step. 


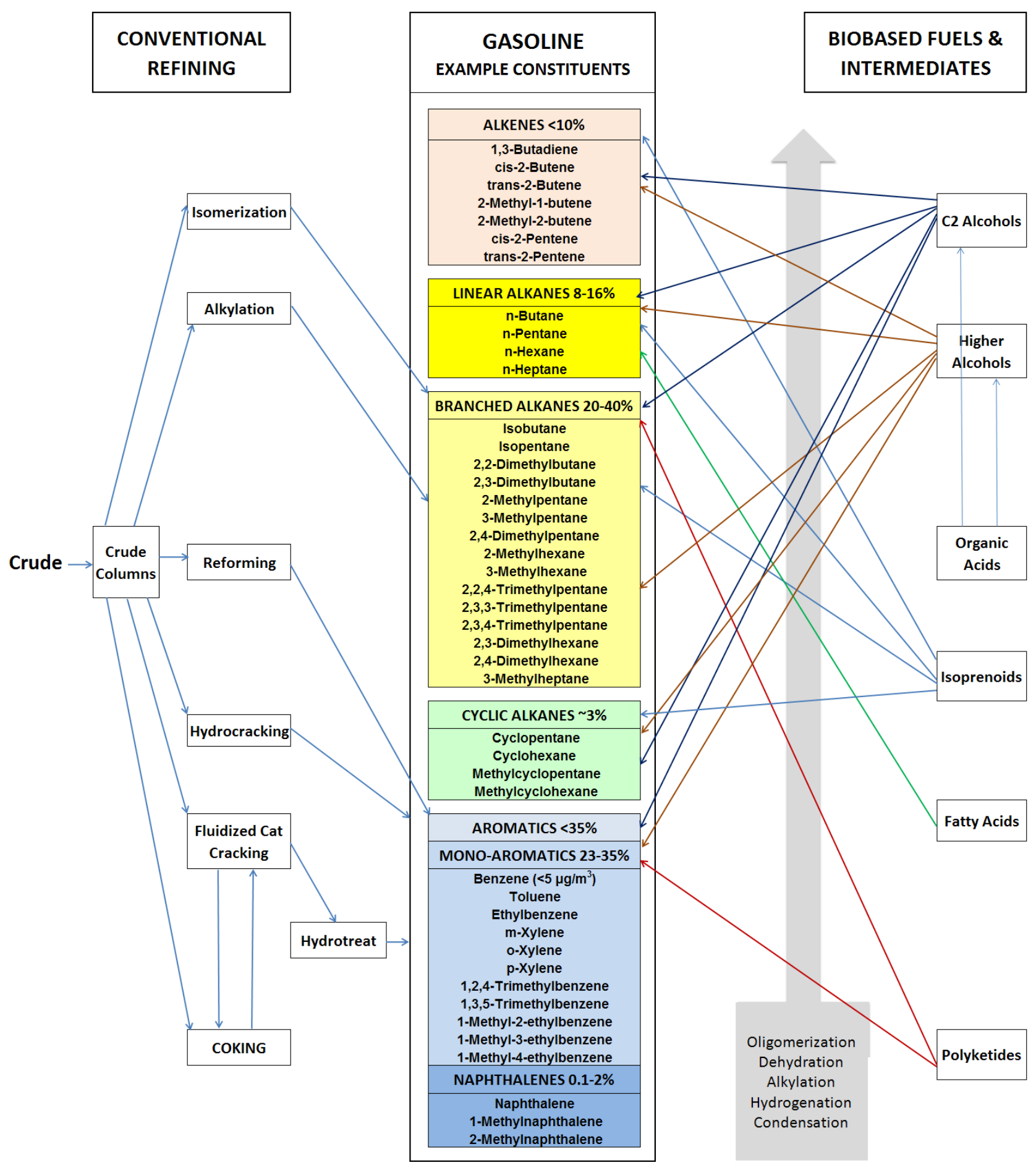

Figure 12. Biobased and Conventional Fuel Process Pathways to Gasoline Constituents 


\begin{tabular}{|c|c|}
\hline JP 8 \\
EXAMPLE CONSTITUENTS
\end{tabular}$\quad \begin{gathered}\text { BIOBASED FUELS \& } \\
\text { INTERMEDIATES }\end{gathered}$
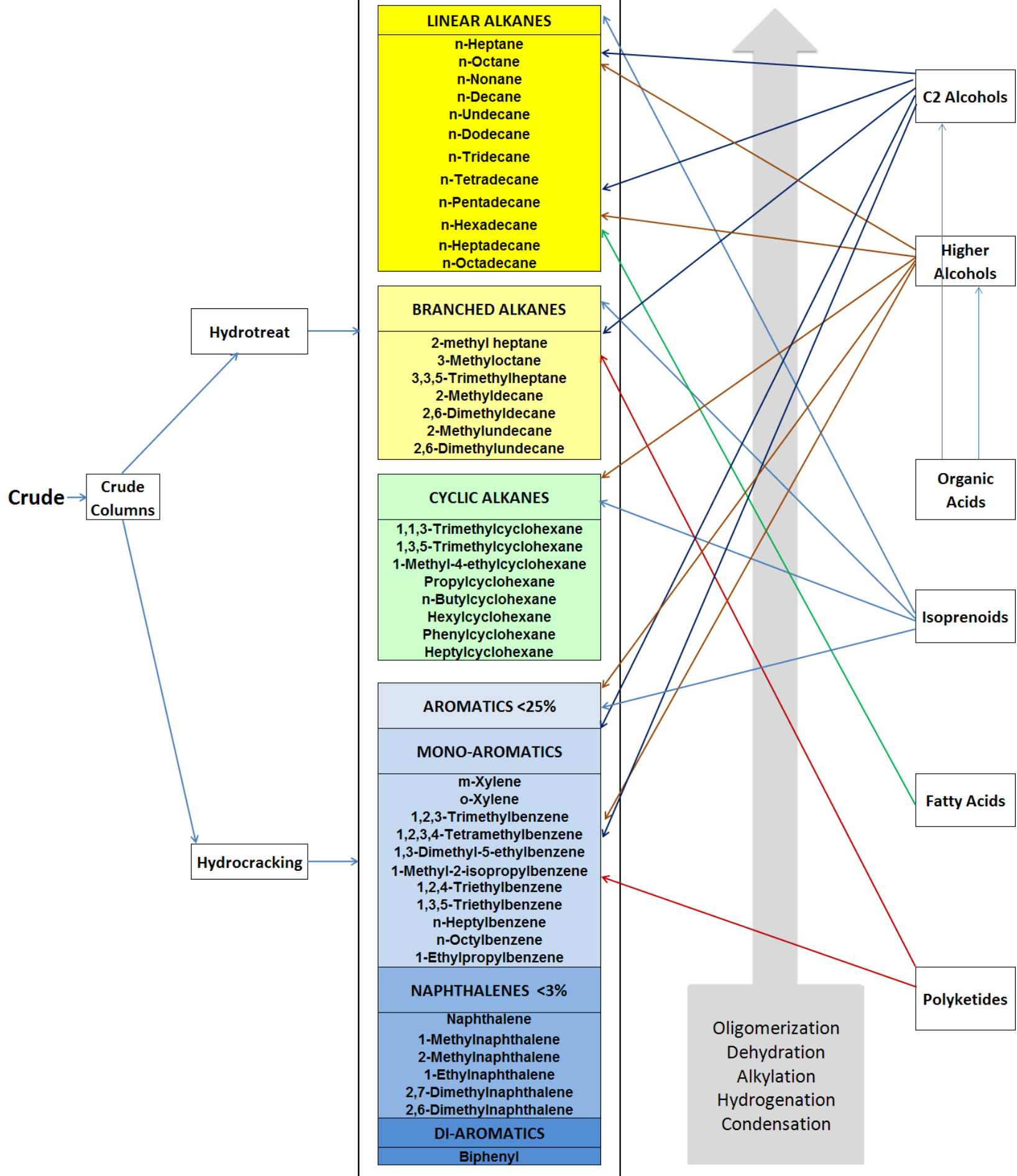

Figure 13. Biobased and Conventional Fuel Process Pathways to JP-8 Constituents 


\section{CONVENTIONAL REFINING}

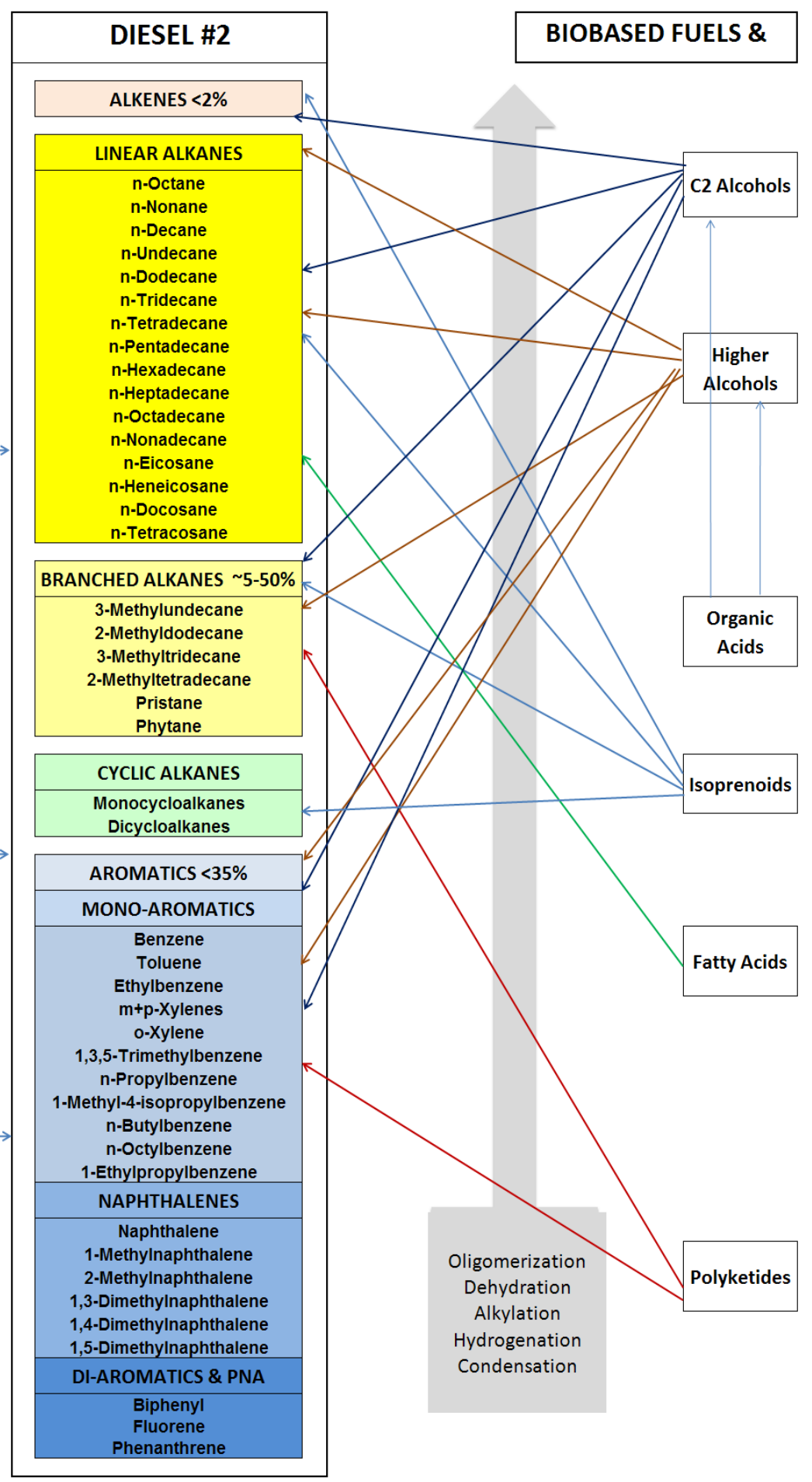

Figure 14. Biobased and Conventional Fuel Process Pathways to Diesel Constituents 


\subsection{Commercialization}

Many companies were identified as current industry leaders in process research and development for biohydrocarbon production. Public documents, such as patents and white papers were reviewed, and in some cases, the companies were directly contacted for more information. Some companies are focusing their research and development around organisms such as E. coli, and select strains of yeast, while others are working with anaerobic bacteria Clostridium sp., Lactobacillus, and Acetogenic bacterium. Major product markets targeted by these companies are transportation fuels such as alcohols, biodiesel, renewable jet fuel, and renewable diesel blend-stocks. A few others are also working in the specialty chemicals market. Given the changing nature of the field, the following list is not meant to be exhaustive, but to provide an overview of much of the industrially significant work related to hydrocarbon type fuels and fuel precursors.

Amyris (Emeryville, CA) focuses on metabolic pathways that produce isoprenoids for the production of renewable diesel, high-value chemicals (anti-malarial), amorphadiene -precursor to Artemycin (antimalarial drugs), as well as Farnesane (fuels) utilizing genetically modified organisms (GMO) yeast and E. coil. The process is based on a sugar cane biomass. Amyris expects their process will be commercially available in 2011 at a 100 million gallon per year (MGY) production rate; the plant is located in Brazil.

CobaltBiofuels (Mountain View, CA) utilizes non GMO Clostridium bacterium for butanol, acetone, and ethanol production. Cellulosic feedstocks are the main carbon source with a two-stage acid hydrolysis pretreatment. CobaltBiofuels also has a patented separation with the potential to reduce separation energy demands by up to 50-75\%. Traditional butanol separation can take $40-70 \%$ of the total production energy. The use of the Clostridium organisms allows use of both hexose and pentose sugars.

Draths (Okemos, MI) is investigating bio-based aromatic replacements identical to petroleum based chemicals. Draths is focused on developing bacterial organisms which operate on sugars. Recently they have patented the lysine-to-caprolactum production process. Although they are not fuel focused, the issues related to bio-chemical development can also apply to fuels.

GEVO (Englewood, CO) uses a GMO yeast strain to produce isobutanol, isooctene and isooctane, renewable jet fuel and renewable diesel blend-stocks. They also have interests in isobutylene and paraxylene production. Their primary feedstock is cellulosic in nature, however they did not disclose their process operations and future commercial goals. An ethanol plant in Missouri was successfully converted to biobutanol last fall 2009. GEVO recently received funding from DOE and USDA for research into biobutanol.

Butamax is a joint venture between BP and DuPont to produce bio-butanol. They claim that their research has advanced sufficiently to allow advancement to the demonstration phase. A demonstration facility in Hull, UK is planned to startup in 2010 and their first commercial plant will be operating in 2013.

LanzaTech, a New Zealand based company, uses non-modified anaerobic bacterium Clostridium sp for ethanol production. Although ethanol is not the focus of this paper, there work is of interest in that they are using flue gas from steel mills (CO gas) as a carbon source. They hope to have a commercially available process by 2012 but they have not disclosed their process production capacity. 
$\underline{\text { LS9, }}$ (San Francisco, CA) primarily produces biodiesel. They use a genetically modified E. coli strain which will ferment both sugarcanes and cellulosic biomass carbon sources. However, the sugarcane source will be used in facilities outside of the US. LS9 hopes to have a small scale demonstration facility completed by mid calendar year 2010, but currently has no plans for larger scale facilities. LS9 has a number of patents that use recombinant techniques engineering organisms to yield fatty acid derivatives such as short chain molecules, fatty acids, fatty acid esters, hydrocarbons and wax esters. LS9 team members recently collaborated with DOE's Joint BioEnergy Institute (JBEI) to engineer a strain of E. coli for biodiesel production.

ZeaChem (Lakewood, $\mathrm{CO}$ ) has a unique process which focuses on ethanol production with lower process $\mathrm{CO}_{2}$ being generated. The process involves first fermenting sugars to acetic acid, convering the acid to ethyl acetate, then hydrogenating the acetate to ethanol. The hydrogen is generated from lignin portion of the cellulosic biomass. The choice organisms in this process are Lactobacillus (lactobacillus casei), and Acetogenic bacterium (Clostridium thermoaceticum). ZeaChem also plans on focusing on cellulosic biomass such as hardwood, softwood, switch grass, corn stover and GreenWood Resoures (GWR) which can be ready identified as hybrid poplar tree. Their major form of pretreatment of the biomass will be enzymatic in nature. $\mathrm{CH} 2 \mathrm{M}$ Hill has been selected to build the first bio-refinery starting in 2009. This demonstration plant is expected to begin operation first quarter of 2010 at a $1 \mathrm{MM}$ gallon a year production rate with full commercialization production goals set at $100 \mathrm{MGY}$. They are also working on a bio-precursor to propylene. These companies are summarized in Table 8.

In addition to the companies listed in Table 8, it should also be noted that a number of companies are working on either normal or iso bio-butanol production. These companies have not yet announced commercial scale ventures:

- Arbor Fuels (www.arborfuels.com),

- Green Biologics, Ltd. (www.greenbiologics.com),

- BUTALCO GmBH (www.butalco.com),

- BioEnergy International (www.bioenergyllc.com),

- TetraVitae Bioscience (www.tetravitae.com).

In summary, several industrial participants have launched major research and development programs which they hope to deploy as economically marketable bio-hydrocarbon processes. However most of the companies screened for this study are in the early stages of strain testing and process development for the fuels and chemicals industry. Even fewer are breaking ground on demonstration facilities. This indicates that still more resources have to be centered on techno-economic evaluation of the products, the potential feedstock, as well as the overall process design and development. 
Table 8. Biofuel Producers

\begin{tabular}{|c|c|c|c|c|}
\hline & $\begin{array}{c}\text { Organism } \\
\text { (Genetically Modified } \\
\text { Organism) }\end{array}$ & Product & $\begin{array}{l}\text { Commercialization: } \\
\text { Production Size }\end{array}$ & Deployment Date \\
\hline $\begin{array}{c}\text { AMYRIS } \\
\text { www.amyrisbiotech.com }\end{array}$ & Yeast, E.coli (GMO) & $\begin{array}{l}\text { Renewable Diesel, } \\
\text { High-Value Chemicals } \\
\text { Anti-malarial Drugs } \\
\text { Farnesane (fuels) }\end{array}$ & 100MGY & 2011 \\
\hline $\begin{array}{c}\text { Butamax } \\
\text { www.butamax.com }\end{array}$ & & Bio-butanol & $\begin{array}{c}\text { \$41 million development } \\
\text { and demonstration plant } \\
\text { in the UK }\end{array}$ & 2010 \\
\hline $\begin{array}{c}\text { CobaltBiofuels } \\
\text { www.cobaltbiofuels.com }\end{array}$ & Clostridium sp. & $\begin{array}{c}\text { Biobutanol } \\
\text { Acetone and Ethanol }\end{array}$ & Demo scale & 2010 \\
\hline $\begin{array}{c}\text { GEVO } \\
\text { www.gevo.com }\end{array}$ & E.coli (GMO) & $\begin{array}{c}\text { Renewable Jet Fuel } \\
\text { Renewable Diesel } \\
\text { (Isobutanol, Isooctene } \\
\text { and Isooctane) } \\
\text { Isobutylene and } \\
\text { Paraxylene }\end{array}$ & $\begin{array}{l}1 \text { million gallon/y } \\
\text { Ethanol plant retrofitted } \\
\text { for isobutanol }\end{array}$ & $9 / 2009$ \\
\hline $\begin{array}{c}\text { LanzaTech } \\
\text { www.lanzatech.nz.com }\end{array}$ & $\begin{array}{l}\text { Anaerobic bacteria, } \\
\text { Clostridium } \mathrm{Sp} .\end{array}$ & $\begin{array}{l}\text { Ethanol from fluegas } \\
\text { fermentation }\end{array}$ & N/A & 2012 \\
\hline $\begin{array}{c}\text { LS9 } \\
\text { www.1s9.com }\end{array}$ & E.coli (GMO) & Diesel & N/A & $\begin{array}{l}\text { Small-scale production } \\
\text { facility by mid- } 2010\end{array}$ \\
\hline
\end{tabular}




\subsection{Economic Considerations}

Preliminary economics assuming currently available technology were estimated to assess the state of technology for a bio-diesel route and a higher alcohol route. These pathways were chosen because they are more near-term pathways than the other routes. Fuels from triacylglycerides (TAGs) are higher boiling molecules that can be used in diesel engines and with additional catalyst upgrading can be used as a jet fuel. Normal butanol, through the AEB route, is a relatively low boiling liquid that can serve as a gasoline blend component.

Figure 15 shows the block flow diagram for n-butanol. Corn stover is washed and size reduced in the feed handling area. Dilute acid pretreatment frees the sugars from the hemicelluloses fraction of the stover. Enzymatic saccharification releases glucose from the cellulose fraction. Lignin is removed by filtration prior to fermentation. Fermentation produces primarily n-butanol and acetone with a lesser amount of ethanol. These three products are removed from the fermentation broth by extraction, and then purified by distillation. Butanol is the prime fuel and credit is taken for acetone and ethanol co-products.

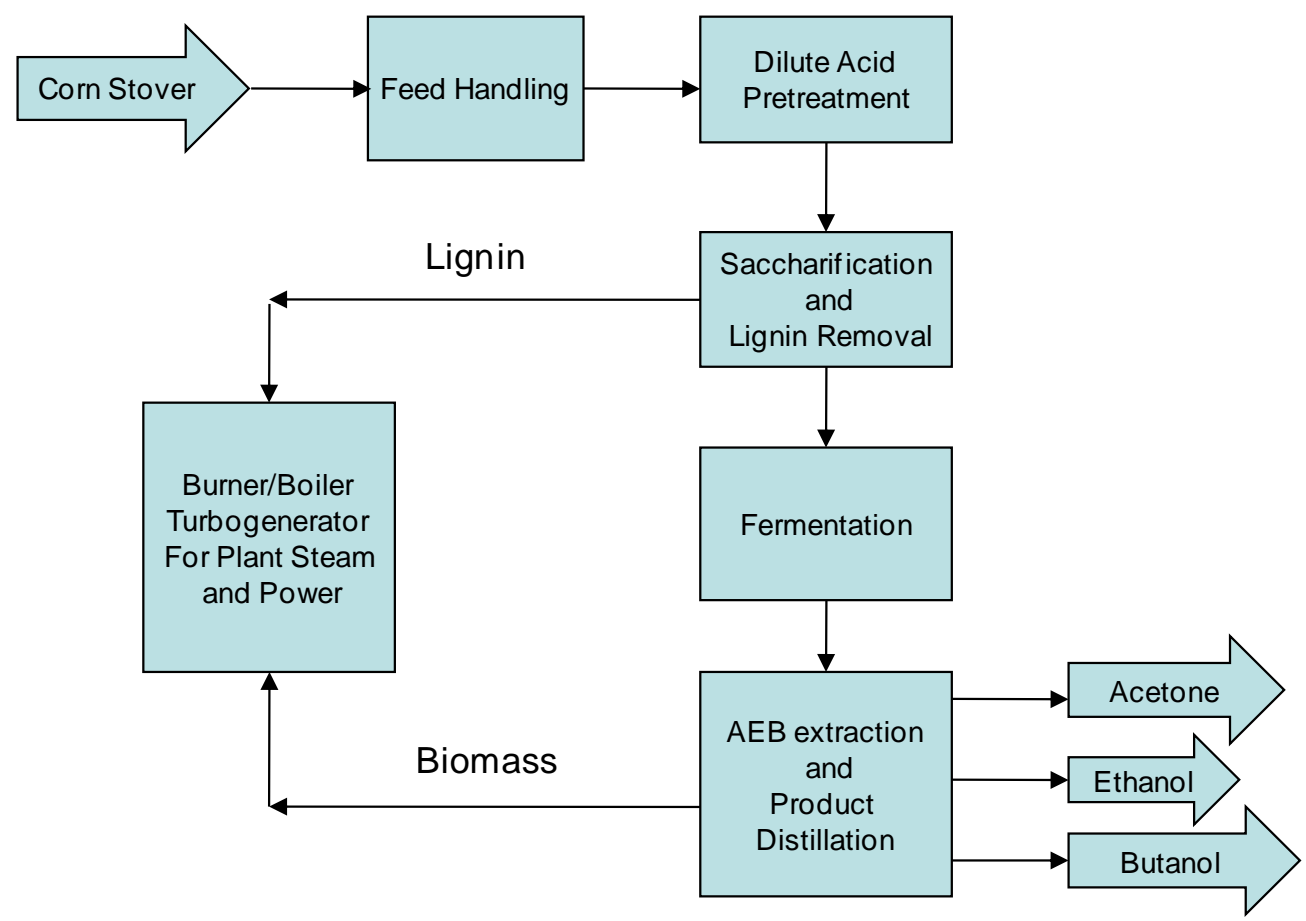

Figure 15. Butanol Block Flow

Figure 16 shows the production of FAME (fatty acid methyl esters) from Corn stover. The stover is washed and reduced in size. Dilute acid pretreatment releases sugars from hemicelluloses. Enzymatic hydrolysis releases cellulosic sugar. Oleagenous organisms are grown on the sugars, until growth is switched to oil accumulation within the cell by withholding nitrogen. The cells are steam lysed, and the oil is extracted from the biomass. The oil is acidified to free the fatty acids, which are then transesterfied with methanol to produce a biodiesel similar to biodiesel today. Glycerol is produced as a co-product. 


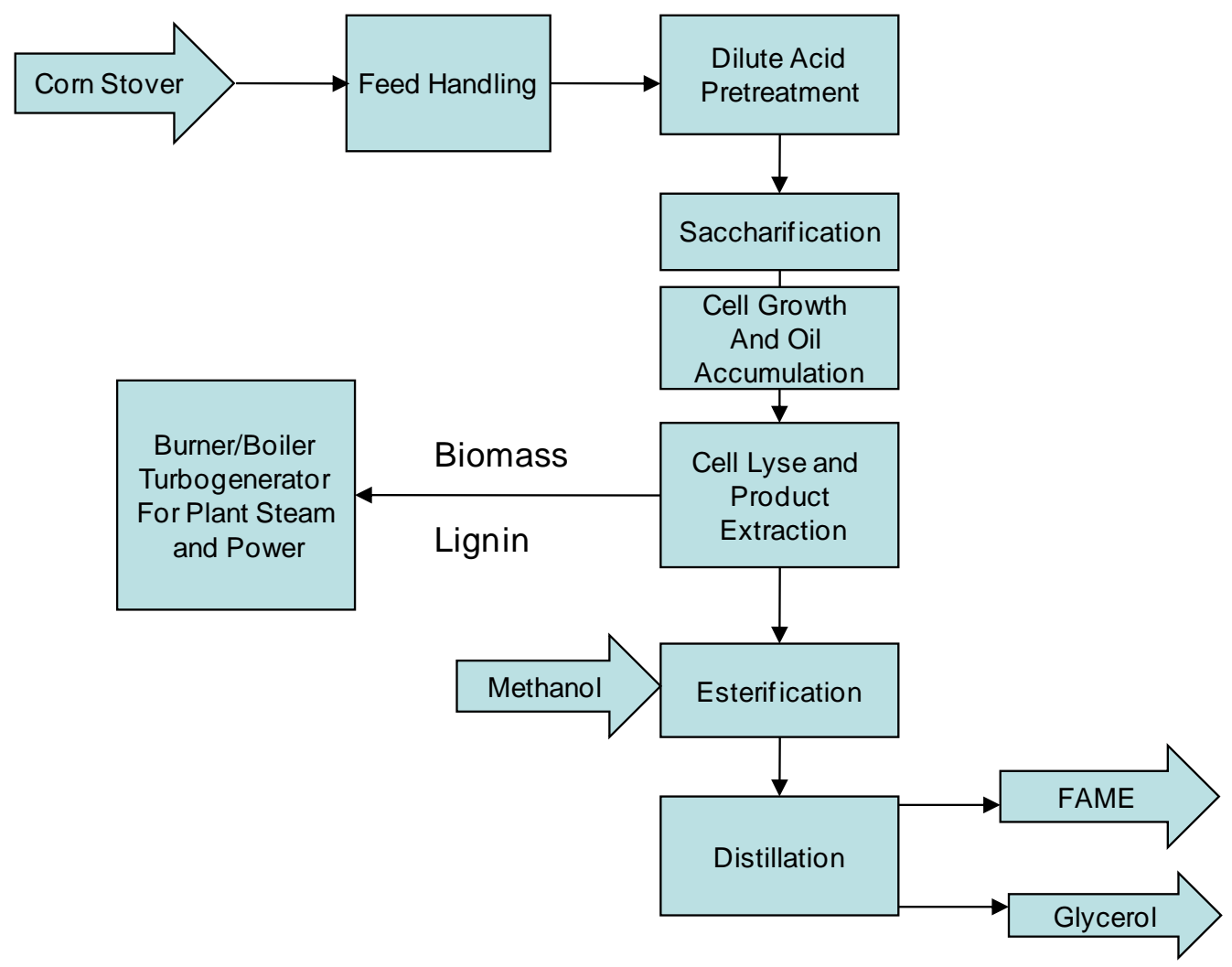

Figure 16. Bio-Diesel Block Flow

The process and costs models are based on publically available information for a cellulosic ethanol plant (Aden 2002) for feed handling, pretreatment and saccharification and utilities. They are intended to serve as a very preliminary assessment of currently available technology. Butanol production is based on the SRI report for bio-butanol (Bohlmann 2007) and FAME production is based on Canakci 2001, Haas 2006, Zhu 2008, and Meng 2009. The main assumptions used to estimate the production costs are:

- An internal rate of return of $10 \%$,

- $\$ 65.30 /$ dry ton corn stover (MYPP 2010),

- Credits taken for by-products,

- 2007 cost basis,

- A Lange Factor of 3.7 (ratio of total capital investment to total bare equipment cost), and

- All other costs based on Aden et al, 2002.

The preliminary economics are based on current yields and technology for butanol and FAME and do not reflect potential improvements. For butanol, the minimum fuel selling price using current technology was estimated to be in the \$5-6/gallon range. This is just above the 2006 selling price for butanol in the chemicals market and well above what a blend price for fuel can be. For the bio-diesel product based on current technology, the production costs are even higher at \$9-10/gallon FAME. The majority of the costs for both cases are in the areas of pretreatment, fermentation, product finishing and recovery, and steam and power generation, as shown in Figure 17. The balance of plant includes biomass preparation, and off- 
sites such as waste water treatment, storage, cooling water and boiler feedwater preparation. Note the high cost for steam and power production. The steam plant burns most of the organic material from the feedstock that is not converted into product and produces plant steam and electricity. Any unused electricity is assumed to be sold. The steam plant fuel consists mostly of lignin and unconverted sugars. The low yields currently possible result in a significant amount of the original biomass burned at the steam plant rather than producing product.

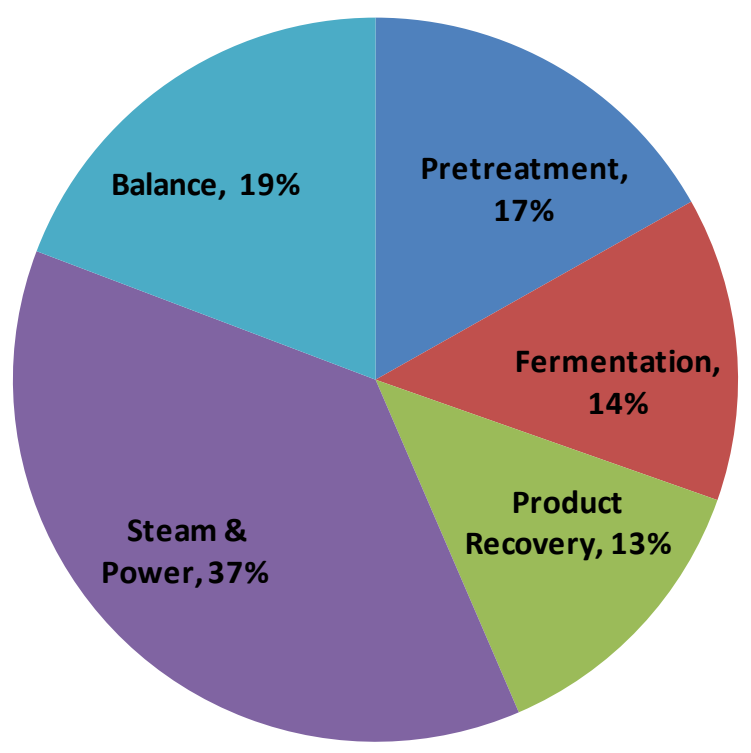

Figure 17. Major Cost Areas

Both pathways have potential for cost reduction. For lipids production, the yield was set at $27 \%$ of the available sugars, which is less than the theoretical maximum, but more than that likely achievable according to Ratledge (2008) for an oleaginous organism. Increasing the yield then, would necessitate engineering an organism to produce the oil outside of the cell. Eliminating fuel finishing steps such as 1) cell lysing to release the oils, and 2) product extraction and separation, and 3) esterification would reduce the capital costs significantly. Doubling the yield and reducing the capital by $50 \%$ reduces the minimum fuel selling price from \$9-10/gallon to less than \$5/gallon. For example, Liu (2007) reports on a method of direct methanolysis that eliminates the extraction step.

For butanol production, the titer is low because of the low organism tolerance for the product. This results in a very dilute broth requiring extraction and distillation to recover the products. Improving the organism's alcohol tolerance and reducing the amount of by-products will increase the yield and reduce product separation costs. For example, Qureshi (2005) reports on an energy efficient butanol recovery method.

Fuel costs through the isoprenoid route and the polyketide route were not modeled, nor were the use of hydrotreating to produce finished fuels because of project scope limitation. For the latter option, hydrogen cost and source will be key to understanding the economics. 


\subsection{Conclusions and Recommendations}

Microbial organisms are capable of producing a wide variety of fuel and fuel precursors. However, low yields and high capital costs are challenges needed to be addressed in order for commodity fuel production to be viable. Specifically, high productivity, titer and efficient conversion are the key factors for success. Identification of highly infrastructure compatible fuels is vital in order to bring these fuels to the market quickly and efficiently. Products not suitable for current fuel infrastructure should be researched for potential non-commodity markets.

Screening economics based on current technology were performed for two of the more developed pathways as a basis for identifying research that could lead to more cost effective commodity fuel production utilizing microbial synthesis pathways. For butanol, the minimum fuel selling price was estimated to be approximately \$5-6/gallon. This is just above the 2006 selling price for butanol in the chemicals market and well above what a blend price for fuel can be. Among other issues butanol is not a true infrastructure ready fuel and therefore less of a favorable molecule for this application. For the biodiesel product from fatty acids, the production costs are estimated to be \$9-10/gallon FAME. Bio-diesel also has process and storage challenges as well as blending problems as it is typically a more viscous fuel then fossil diesel fuel. However, Akoh (2007) suggests in his review that enzymatic production of diesel through the use of lipases 'is the way of the future.'

Research areas in particular are:

- Increase yields and production rates. Currently, butanol production rates are lower than ethanol. Hydrocarbon producers are even less with yields of $1-2 \%$ of the glucose, unless they are oleaginous.

- Improve pre-treatment and chemical by-product poison tolerance of the organism,

- Improve organism tolerance to the end product,

- Identify and engineer new organism bio-pathways which can create larger extracellular molecules excreted by transporter proteins or by diffusion,

- Attain in-situ product recovery from fermentation broth by applying innovative separations.

Fischer et al 2008, suggests that product yield may be the easiest to biologically engineer because experimental tools are already in place. Effective methods for titer and productivity improvement still have to be developed, possibly through the use of fed batch processing or immobilized cell cultures. However, implementing these types of processing methods in a lignocellulosic feedstock plant is challenging due to nature of the feedstock. Additionally the use of pentose and minor sugars as well as managing lignin is also important in next generation plants. More laboratory research has to be directed in this area through the use of genetic engineering methods of selected organisms.

The purpose of this report is to provide preliminary information needed to map directions for research into the rich field of microbially produced fuel precursors and infrastructure compatible fuels. For example, the isoprenoid, fatty acid and polyketide pathways to fuels and fuel precursors hold promise. However, energy demands and byproducts of these pathways require further exploration. In particular, detailed stoichiometric balances incorporating energy needed for organism growth and that for product generation for all the pathways of interest would help clarify the balance between these two needs. Some 
of these data are already available, such as the pathways derived from fungal organism work at PNNL. From here, pathway specific screening economics can be developed to help clarify promising pathways that can be further developed into design cases.

Lastly achieving a finished product through these pathways is often dependent on post processing such as hydrotreating. Understanding hydrogen usage and sources are likely to be key drivers in the development of an economic and sustainable product that meets the definition of an advanced fuel. 


\subsection{References}

Aden, A. et al. (2002) "Lignocellulosic Biomass to Ethanol Process Design and Economics Utilizing CoCurrent Dilute Acid Prehydrolysis and Enzymatic Hydrolysis for Corn Stover" NREL/TP-51032438

Ajikumar, P.K. et al. (2008) "Terpenoids: Opportunities for Biosyntehsis of Natural Product Drugs Using Engineered Microorganisms" Molecular Pharmaceutics 5(2):167-190

Akoh, Casimir, et al. (2007) "Enzymatic Approach to Biodiesel Production” Journal of Agricultural and Food Chemistry 55:8995-9005

Anthony, J. R., et al. (2009) "Optimization of the Mevalonate-Based Isoprenoid biosynthetic pathway in Escherichia coli for Production of the Aanti-Malarial Drug Precursor Amorpha-4,11-diene." Metabolic Engineering 11(1): 13-19.

Antizar-Ladislao, Blanca, et al. (2008) "Second-Generation Biofuels and Local Bioenergy Systems" Biofuels, Bioproducts \& Biorefining 2:455-469

Atsumi, Shota et al. (2007) "Non-Fermentive Pathways for Synthesis of Branched-Chain Higher Alcohols as Biofuels" Nature 451:86-89

Atsumi, Shota and James Liao (2008) "Metabolic Engineering for Advanced Biofuels Production from Excherichia Coli" Current Opinion in Biotechnology 19:414-419

Bacha, John et al.(2007) "Diesel Fuels Technical Review”. Chevron Corporation http://www.chevron.com/products/prodserv/fuels/technical safety bulletins

Berg, Jeremy et al.(2002) “Chapter 22: Fatty Acid Metabolism” Biochemisty, $5^{\text {th }}$ Edition W.H. Freeman, New York

Bohlmann (2007) PEP Review 2007-1 Biobutanol. SRI Process Economics Program. SRI Consulting, Menlo Park, CA

Butamax (2010) www.butamax.com

Canakci M, Van Gerpen J, 2001"Biodiesel production from oils and fats with high free fatty acids" Transactions of the ASAE 44(6), 1429-1436 (2001)

Chang, Michelle, et al. (2006) "Production of Isoprenoid Pharmaceuticals by Engineered Microbes" Nature Chemical Biology 2(11):674-681

Chen, Xi et al. (2009) "Screening of Oleaginous Yeast Strains Tolerant to lignocelluloses Degradation Compounds" Applied Biochemistry and Biotechnology 159:591-604

Daum, Martina et al. (2009) "Genes and Enzymes Involved in Bacterial Isoprenoid Biosynthesis" Current Opinion in Chemical Biology 13:180-188

Dembitsky, Valery (2006) “Astonishing Diversity of Natural Surfactants: 7. Biologically Active Hemiand Monoterpenoid Glycosides", Lipids, 41(1):1-27

EISA (2007) $110^{\text {th }}$ United States Congress, H.R. 6: Energy Independence and Security Act, January 2007. 
Eisenreich, W. et al. (2004) "Biosynthesis of Isoprenoids via Non-Mevalonate Pathway" Cellular and Molecular Life Sciences 61:1401-1426

Ezeji, T. C., et al. (2005). "Continuous Butanol Fermentation and Feed Starch Retrogradation: Butanol Fermentation Sustainability Using Clostridium beijerinckii BA101" Journal of Biotechnology 115(2): 179-187.

Ezeji, T., et al. (2007) "Bioproduction of Butanol from Biomass: from Genes to Bioreactors" Current Opinion in Biotechnology 18(3): 220-227.

Fahy, E. et al. (2005) "A Comprehensive Classification System for Lipids" Journal of Lipid Research 46: $839: 861$

Fischer, Curt R. et al. (2008) "Selection and Optimization of Microbial Hosts for Biofuels Production" Metabolic Engineering 10:295-304

Fortman, J. L., et al. (2008) "Biofuel Alternatives to Ethanol: Pumping the Microbial Well" Trends in Biotechnology 26(7): 375-381

Gibb, Jay et al. (2009) "Motor Gasolines Technical Review FTR-1" Chevron Corporation http://www.chevron.com/products/prodserv/fuels/technical_safety_bulletins/

Haas, Michael J., et al. (2006) "A Process Model to Estimate Biodiesel Production Costs", Bioresource Technology 97:671-678

Hemighaus, Greg et al. (2004) "Aviation Fuels Technical Review (FTR-3)” Chevron Corporation http://www.chevron.com/products/prodserv/fuels/technical_safety_bulletins/

Hemighaus, Greg et al. (2006) “Alternative Jet Fuels” Chevron Corporation http://www.chevron.com/products/prodserv/fuels/technical safety bulletins/

Hertwick, Christian (2009) "The Biosynthetic Logic of Polyketide Diversity” Angewandte Chemie 48:4688-4716

Hileman, James et al. (2009) "Near-Term Feasibility of Alternative Jet Fuels" Rand Technical Report. Rand Corporation and Massachusetts Institute of Technology www.rand.org/publications

Holmger, Jennifer et al. (2007) "New Developments in Renewable Fuels Offer More Choices" Hydrocarbon Processing 86:59-72

Keasling, Jay, et al. (2008) "Metabolic Engineering Delivers Next-Generation Biofuels" Nature Biotechnology 26(3):298-299

Khosla, Chaitan, et al (1999) “Tolerance and Specificity of Polyketide Synthases” Annual Review of Biochemistry 68:219-253

Kinder, James and Timothy Rahmes (2009) Evaluation of Bio-Derived Synthetic Paraffinic Kerosene (Bio-SPK), The Boeing Company. June 2009

www.boeing.com/aboutus/govt_ops/reports_white_papers/pas_biofuel_exec_summary.pdf

Kreamer, Naomi and Carol Gross (2010) University of Minnesota Biofuels Database 1.15.4, https://www.bioguelsdatabase.rog/wiki/index.php5/Main_page

Jiang, Yu et al. (2009) "Disruption of the Acetoacetate Decarboxylase Gene in Solvent-Producing Clostridium acetobutylicum Increases the Butanol Ratio” Metabolic Engineering 11:284-291 
Julsing, Mattijs, et al. 2007 "Functional Analysis of Genes Involved in the Biosynthesis of Isoprene in Bacillus subtilis" Applied Microbiology and Biotechnology 75:1377-1384

Ladygina, N., et al. (2006) "A Review on Microbial Synthesis of Hydrocarbons." Process Biochemistry 41(5): 1001-1014.

Lee, S. K., et al. (2008) "Metabolic Engineering of Microorganisms for Biofuels Production: from Bugs to Synthetic Biology to Fuels." Current Opinion in Biotechnology 19(6): 556-563.

Lehninger, A. L. (1978) Biochemistry, Worth Publishers, Inc.

Li, Han et al. (2010) "Biofuels: Biomolecular Engineering Fundamentals and Advances" Annual Review of Chemical and Biomolecular Engineering 1:19-36

Liu, Bo et al. (2007) "Biodiesel Production by Direct Methanolysis of Oleaginous Microbial Biomass" Journal of Chemical Technology and Biotechnology 82:775-780

Magnuson, Kelly, et al. (1993) "Regulation of Fatty Acid Biosynthesis in Escherichia coli" Microbiological Reviews 57(3):522-542

Maury, J., et al. (2005) Microbial isoprenoid production: An example of green chemistry through metabolic engineering. Biotechnology for the Future. Berlin, Springer-Verlag Berlin. 100: 19-51.

Meng, Xin, et al (2009) "Biodiesel Production from Oleaginous Microorganisms" Renewable Energy $34: 1-5$

Metzler, D. (2001) Biochemistry: The Chemical Reactions of Living Cells, Academic Press.

Murley, Andrew (2009) “Aliphatic and Isoprenoid Hydrocarbon Biosynthesis for Diesel Fuels" $\underline{\mathrm{MMG}}$ 445 Basic Biotechnology eJournal 5(1):1-7 accessed online at http://ejournal.vudat.msu.edu/index.php/mmg445/article/viewAtricle/386/351

MYPP 2010, Department of Energy, Energy Efficiency and Renewable Energy Biomass Program MultiYear Program Plan, March 2010. www.eere.energy.gov/biomass/pdfs/mypp.pdf

Potter, Thomas L. and Kathleen Simmons "Vol 2. Composition of Petorleum Mixtrues" Total Petroleum Hydrocarbon Criteria Working Group Series, May 1998, Amherst Scientific Publishers

Qureshi, N. et al. (2005) "Energy-Efficient Recovery of Butanol form Model Solutions and Fermentation Broth by Adsorption" Bioprocessing and Biosystems Engineering 27:215-222

Ratledge, Colin (2004) "Fatty Acid Biosynthesis in Microorganisms Being Used for Single Cell Oil Production” Biochimie 86:807-815

Ratledge, Colin et al. (2008) "Microbial and Algal Oils: Do They Have a Future for Biodiesel of as Commodity Oils?” Lipid Technology 20(7):155-160

Renninger, N.S. et al. (2008) "Fuel Compositions Comprising Farnesane and Farnesane Derivatives and Method of Making and Using the Same" US 7,399,323,B2

Robinson, Richard, editor. 2000 “Lipid Metabolism” Encyclopedia of Food Microbiology, Elsevier Press. Accessed through www.knovel.com

Roderiguez-Concepcion, Manuel et al (2002) "Elucidation of the Methylerytritol Phosphate Pathway for Isoprenoid Biosynthesis in Bacteria and Plastids" Plant Physiology 130: 1079-1089 
Rottig, Annika (2010) "Fatty Acid Alkyl Esters: Perspectives for Production of Alternative Biofuels" Applied Microbiology and Biotechnology 85:1713-1733

Rude, Mathew, et al (2009) "New Microbial Fuels: A Biotech Perspective" Current Opinion in Microbiology 12:274-281

Seemann, M., N. Campos, et al. (2002) "Isoprenoid Biosynthesis in Escherichia coli via the Methylerythritol Phosphate Pathway: Enzymatic Conversion of Methylerythritol cyclodiphosphate into a Phosphorylated Derivative of (E)-2-methylbut-2-ene-1,4-diol" Tetrahedron Letters 43(8): 1413-1415.

Shen, Ben (2003) "Polyketide Biosyntehsis Beyond the Type I, II and III Polyketide Synthase Paradigms" Current Opinion in Chemical Biology 7: 285-295.

Shen, C. R. and J. C. Liao (2008) "Metabolic Engineering of Escherichia coli for 1-Butanol and 1Propanol Production via the Keto-acid Pathways" Metabolic Engineering 10(6): 312-320.

Shiba, Y., et al. (2007) "Engineering of the Pyruvate Dehydrogenase Bypass in Saccharomyces cerevisiae for High-level Production of Isoprenoids" Metabolic Engineering 9(2): 160-168.

Strobel, Gary A., et al. (2008) "The Production of Myco-Diesel Hydrocarbons and Their Derivatives by the Endophytic Fungus Gliocladium rosium (NRRL 50072)" Microbiology 154:3319-3328

Vine, Leland M. (2008) "Separation Technology for the Recovery and Dehydration of Alcohol from Fermentation Broths" Biofuels, Bioproducts and Biorefining 2:553-588

Wackett, Lawrence P. (2008) "Biomass to Fuels via Microbial Transformations" Current Opinion in Chemical Biology 12:187-193

Wackett, L.P. (2008) "Microbial-Based Motor Fuels: Science and Technology" Microbial Biotechnology 1(3):211-225

Waltermann, Marc (2006) "Wax Ester and Triacylglycerol Inclusions” Inclusions in Prokaryotes, Microbology Monograph Series, J.M Shively editor, Springer-Verlag, Berlin

Wynn, James P, et al. (2001) "Biochemical Events Leading to the Diversion of Carbon into Storage Lipids in the Oleaginous Fungi Mucor circinelloides and Mortierella alpina" Microbiology $147: 2857-2864$

Yan, Yajun and J.C. Laio (2009) "Engineering Metabolic Sytems for Production of Advanced Fuels" Journal of Industrial Microbiology and Biotechnology, 36:471-479

Zhu, L.Y. et al. 2008 "Efficient lipid production with Trichosporon fermentans and its use for biodiesel preparation", Bioresource Technology 99:7881-7885 


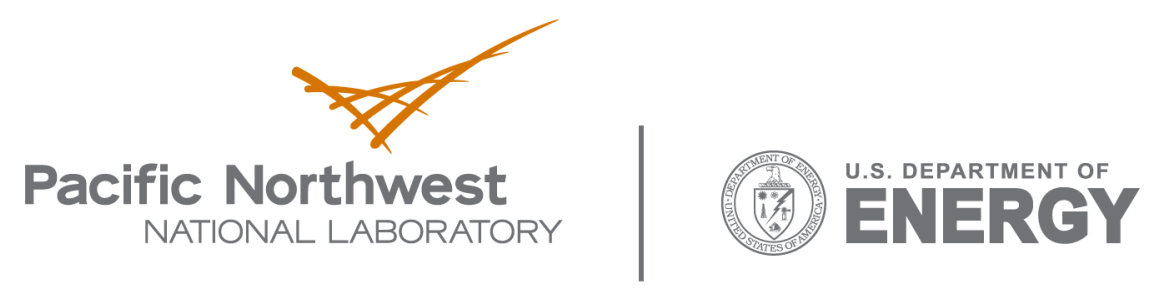

902 Battelle Boulevard

P.O. Box 999

Richland, WA 99352

1-888-375-PNNL (7665)

www.pnl.gov 